\title{
Iron-Mediated Reversible Deactivation Controlled Radical Polymerisation
}

\author{
Rinaldo Poli, ${ }^{*, a-c}$ Laura E. N. Allan ${ }^{\mathrm{d}}$ and Michael P. Shaver*,d \\ ${ }^{\text {a }}$ CNRS, LCC (Laboratoire de Chimie de Coordination), 205 route de Narbonne, BP \\ 44099, F-31077, Toulouse Cedex 4, France. \\ ${ }^{\mathrm{b}}$ Universite de Toulouse, UPS, INPT, F-31077, Toulouse Cedex 4, France \\ ${ }^{\mathrm{c}}$ Institut Universitaire de France, 103, bd Saint-Michel, 75005, Paris, France \\ ${ }^{\mathrm{d}}$ School of Chemistry, University of Edinburgh, West Mains Road, Edinburgh, EH9 \\ 3JJ, United Kingdom.
}

Corresponding author: michael.shaver@ed.ac.uk, +44 1316504726

\begin{abstract}
Metal-mediated reversible deactivation radical polymerisation (RDRP) is now a cornerstone of functional polymer synthesis, dominated by copper complexes and the Atom Transfer Radical Polymerisation (ATRP) moniker. A limitation of this approach is the contamination of the resultant polymers by the coloured copper complexes, requiring purification steps, although protocols to reduce the amount of copper catalyst have been developed. Iron is an interesting alternative because of its low cost, low toxicity and reduced intensity of its optical absorption spectrum. Use of this metal in RDRP began in the late 90s and has continuously intensified. This review comprehensively covers all the work reported so far on RDRP mediated by iron complexes, organised according to ligand type, and discusses the specificities of this metal in terms of the multitude of accessible spin states and the interplay of different equilibria: atom transfer $v s$. direct radical trapping, associative $v s$. dissociative exchange, chain transfer by direct $\beta-\mathrm{H}$ atom transfer $v s$. $\beta-\mathrm{H}$ elimination from the dormant alkyl species.
\end{abstract}

\section{Keywords}

Iron; Radical polymerisation; Atom transfer radical polymerisation; Organometallic mediated radical polymerisation; Reversible deactivation radical polymerisation.

\section{Table of Contents}

1. Introduction

2. Early Years (1997-1999)

3. Use of Iron Complexes in Reversible Deactivation Radical Polymerisation

3.1.Phosphine Ligands

3.2.Imine Ligands

3.3.Amine Ligands

3.4.Other ligands

3.5.No External Ligands

3.6.Acid Additives

3.7.Salt Additives

3.8.Monomer and Macrostructure Scope

4. Mechanistic Features of RDRP with iron complexes 
4.1."Pure" ATRP processes

4.2.Reducing the amount of Fe catalyst in ATRP

4.3.AGET-ATRP: Is a reducing agent necessary?

4.4.Interplay of ATRP and RT-OMRP

4.5.OMRP processes

4.6.Interplay of ATRP, RT-OMRP and CCT

4.7.Lessons Learned in Designing Fe Systems for RDRP

5. Conclusions

\section{Introduction}

Since its development nearly 30 years ago, ${ }^{1-9}$ controlled radical polymerisation has proven to be one of the most prolific contributions to modern polymer chemistry. Maintaining the functional group tolerance of conventional radical polymerisation whilst offering control over molecular weight, dispersity (Đ) and macromolecular architecture has opened new avenues into a multitude of versatile advanced materials. ${ }^{10-29}$ IUPAC generalises the strategies to achieve this control as reversibledeactivation radical polymerisations (RDRP) but the individual techniques are commonly referred to by the specific strategy exploited to maintain control. Two general families of RDRP can be clearly distinguished, namely those involving dissociation of the reactive radical from a dormant species (Figure 1a) and those involving associative exchange of the reactive radical with the dormant species, which also plays the role of transfer agent (Figure 1b). In the former case a rapid, dynamic equilibrium between dormant and growing radical chains lowers the radical concentration, minimising bimolecular termination reactions. These dissociative RDRP techniques benefit from the so-called "persistent radical effect" 30 (although the trapping reagent, $\mathrm{T}$, need not be a "stable", or persistent, free radical) and the polymerisations are slower than conventional free radical polymerisations, with an approximately first order rate law, although power laws have also been observed for some RDRP techniques. ${ }^{31}$ In the second RDRP category there is no persistent radical effect. Rapid degenerative exchange in combination with a chain length-dependent termination rate ensures pseudo-living growth, as long as an influx of new radicals from a conventional radical initiator is maintained. The polymerisation rate is regulated by the rate of radical production from the initiator, as in free radical polymerisation. 
(a)

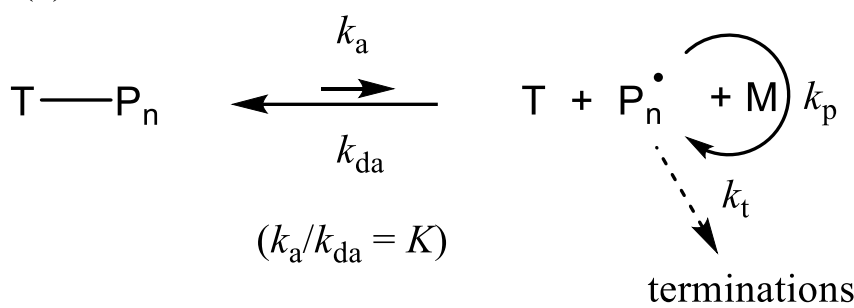

(b)

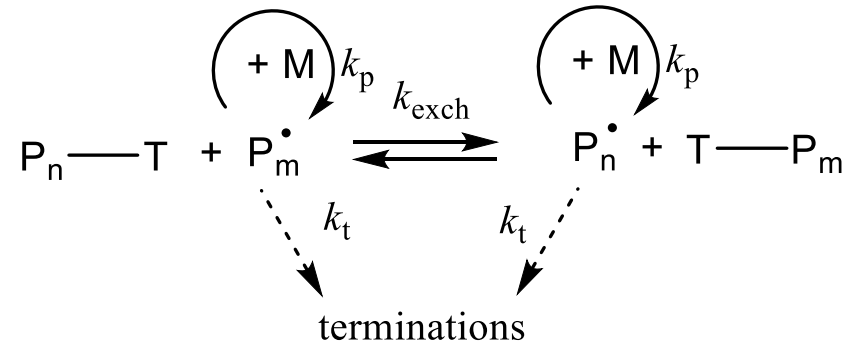

Figure 1. General mechanisms of RDRP: (a) dissociative radical generation; (b) associative radical exchange.

Of these RDRP strategies, metal-mediated methods have developed into a powerful workhorse for scientists to produce specialised polymers due to their ease of use, advanced control over metal complex concentration, excellent end-group fidelity and monomer and initiator scope. Metal complexes can mediate RDRP in three different ways, with possible interplay between two or more different modes in certain cases. ${ }^{32}$ A metal complex can act as the trapping species, $\mathrm{T}$, in a reversible deactivation approach (Figure 1a), yielding a dormant species that contains a metal-carbon bond (termed Organometallic Mediated Radical Polymerisation, OMRP). Wayland reported the first example of OMRP in 1994, utilising a cobalt porphyrin complex to mediate acrylate polymerisation. ${ }^{6}$ However, if the dormant species has a suitable structure, it can also act as a transfer agent for degenerative transfer polymerisation (Figure 1b). ${ }^{33,34}$ There are therefore two mechanistically distinct OMRP strategies, one dissociative (reversible termination, or RT-OMRP) and the other one associative (degenerative transfer, or DT-OMRP). The third metal-mediated RDRP method is Atom Transfer Radical Polymerisation (ATRP), a dissociative-type mechanism where the trapping species, $\mathrm{T}$, is an oxidised metal halide complex, $\mathrm{X}-\mathrm{Mt}^{\mathrm{x}+1} / \mathrm{L}$. Rather than forming a direct bond, however, $\mathrm{T}$ transfers a halogen atom and yields a halogenterminated dormant species and a reduced metal complex, $\mathrm{Mt} / \mathrm{L}$, which is therefore a catalyst (Figure 2). ATRP, first reported in 1995 by Matyjaszewski for a $\mathrm{Cu}^{\mathrm{I}} / \mathrm{Cu}^{\mathrm{II}}$ system $^{7}$ and Sawamoto for a $\mathrm{Ru}^{\mathrm{II}} / \mathrm{Ru}^{\mathrm{III}}$ system, ${ }^{8}$ also benefits from the persistent

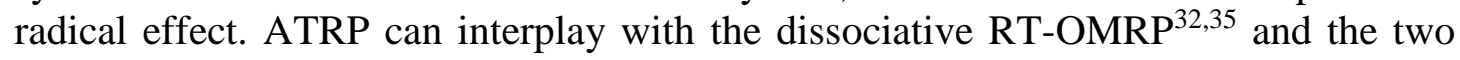
(associative and dissociative, DT and RT) OMRP methods may also operate for the same system. ${ }^{33,36}$ 


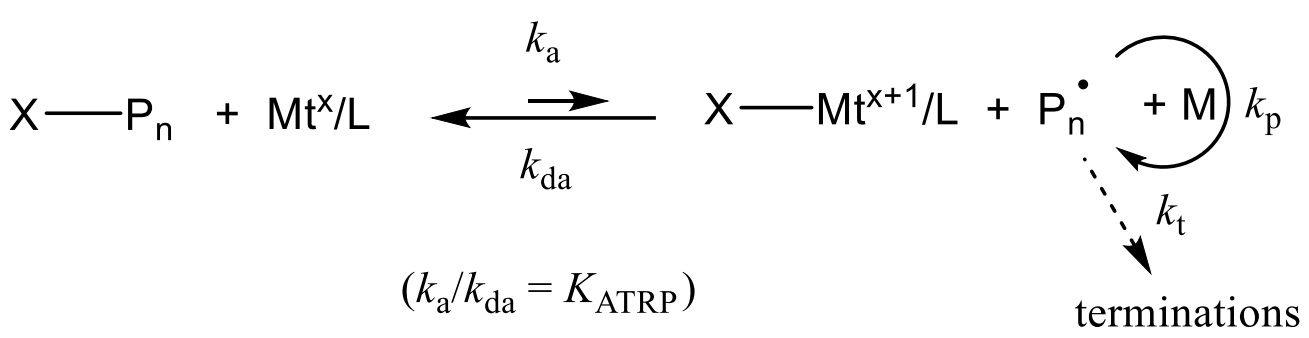

Figure 2. The ATRP mechanism.

Both dissociative metal-mediated polymerisations (ATRP and RT-OMRP) can be set up either from a molecular analogue of the dormant species or from the trapping species and a conventional radical initiator. In ATRP, starting from an alkyl halide (or pseudo halide) compound allows a molecule with the appropriate bond strength to be selected from a broad range of available initiators, leading to fast initiation and polymers with narrow Đ. However, this requires using the more sensitive, reduced, $\mathrm{Mt}^{\mathrm{x}} / \mathrm{L}$ complex which can be difficult to handle. Using the alternative strategy (often referred to as "reverse ATRP" or R-ATRP) has the advantage of utilising the more stable oxidised metal complex in conjunction with a conventional radical initiator. For control to be maintained, the initiator must decompose quickly enough to be completely consumed in a short time relative to the time required for the polymerisation process. Modified strategies also exist, for instance the oxidised complex may be reduced in situ to the catalyst in the presence of the alkyl halide initiator by a reducing agent incapable of acting as a radical initiator such as tin(II) octanoate, glucose or ascorbic acid (Activator Generated by Electron Transfer, AGET-ATRP) ${ }^{37}$ In dissociative RT-OMRP, the availability of organometallic species with suitably weak metal-carbon bonds, $\mathrm{R}_{0}-\mathrm{Mt}^{\mathrm{x}+1} / \mathrm{L}$, to use as unimolecular initiators is quite limited. Thus, the reactions are more frequently set up under "reverse" conditions, starting from $\mathrm{Mt}^{\mathrm{x}} / \mathrm{L}$ and a conventional radical initiator. The associative DT-OMRP may, in principle, be initiated from an organometallic molecule, $\mathrm{R}_{0^{-}}$ $\mathrm{Mt}^{\mathrm{x}+1} / \mathrm{L}$, and a conventional radical initiator. However, for the above stated reason of limited availability, it is more practical to start from $\mathrm{Mt}^{\mathrm{x}} / \mathrm{L}$ and excess conventional radical initiator. In the presence of monomer, the first equivalent of radicals transforms $\mathrm{Mt}^{\mathrm{x}} / \mathrm{L}$ to short $\mathrm{P}_{\mathrm{n}}-\mathrm{Mt}^{\mathrm{x}} / \mathrm{L}$ oligomers, potentially with the contribution of RT-OMRP, and the subsequent excess radicals then trigger the associative exchange mechanism.

Besides facilitating mechanisms which enable radical polymerisations to achieve controlled chain growth through reversible radical trapping, atom transfer and associative radical exchange processes, transition metal complexes can also interact with radicals in ways that may negatively interfere with controlled growth. The most important of these processes is $\mathrm{H}$-atom transfer from the $\beta-\mathrm{C}$ atom of the active radical chain to the reduced $\mathrm{Mt}^{\mathrm{x}} / \mathrm{L}$ complex, resulting in a dead chain with an unsaturated end-group and a hydride complex, $\mathrm{H}-\mathrm{Mt}^{\mathrm{x}+1} / \mathrm{L}$. The latter may be capable of transferring the $\mathrm{H}$-atom to a new monomer, yielding a Catalysed Chain Transfer (CCT) radical polymerisation (Figure 3). ${ }^{38}$ This process directly competes with reversible radical trapping in RT-OMRP, since both involve the same two components. An H-atom transfer process may also take place via the organometallic adduct, if this is capable of undergoing $\beta-\mathrm{H}$ elimination. ${ }^{39}$ In addition, the radical chain may add at a ligand position, if sufficient spin density is located there, or 
abstract an $\mathrm{H}$-atom from a ligand, particularly when monomers that generate reactive radicals are being polymerised. For these reasons, proper engineering of the metal coordination sphere is an important aspect of metal-mediated RDRP. Last but not least, the growing radical chain may also react with the OMRP dormant chain or with the hydride intermediate of the CCT process resulting in a catalysed termination process (Figure 4). ${ }^{40}$ The possible ways in which transition metal complexes are known to react with organic radicals have been discussed in a recent review. ${ }^{41}$

CCT
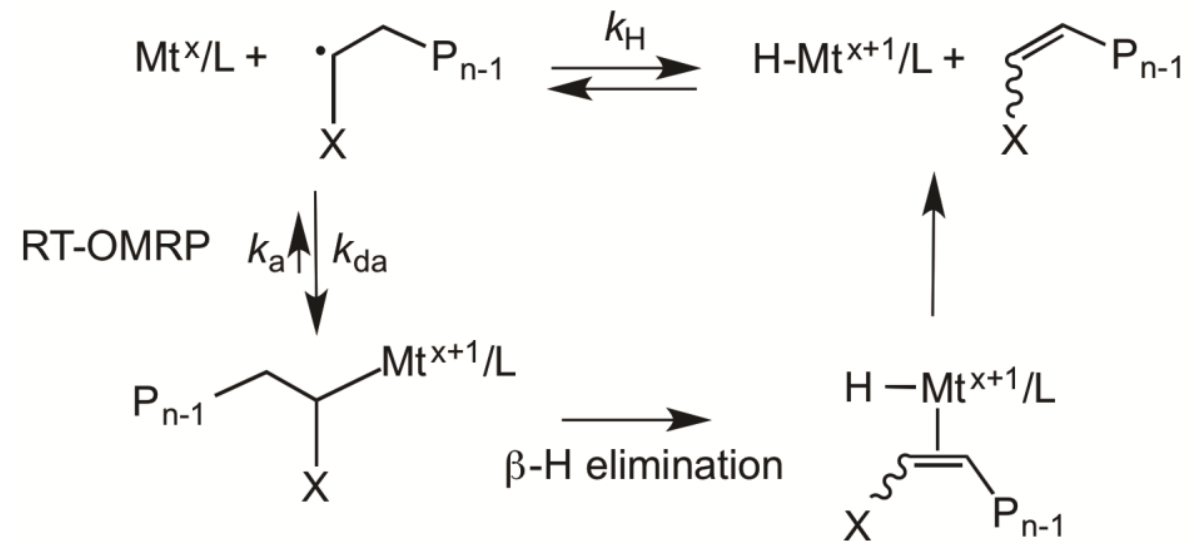

Figure 3. Different pathways involving a metal complex $\mathrm{Mt}^{\mathrm{x}} / \mathrm{L}$ and an organic radical.

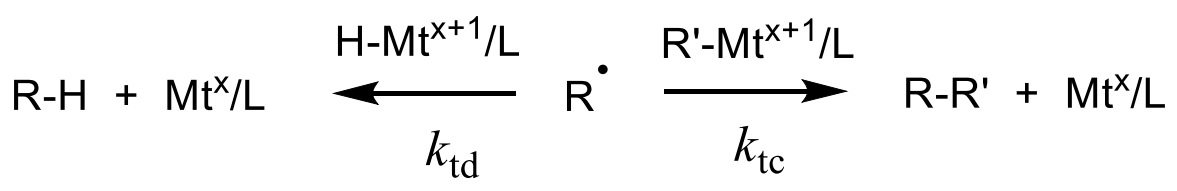

Figure 4. Different pathways leading to a catalysed radical termination process.

ATRP dominates the RDRP landscape, with the ubiquitous copper systems offering control over homopolymerisations, block copolymerisations, surface and star initiated radical polymerisations. ${ }^{19}$ However, concerns remain about the toxicity of copper and the colour remaining in the isolated polymer products. To this end, numerous elegant strategies to lower the metal concentration have been developed, recognising that control is achieved not by the total concentration of metal but rather by the relative concentrations of $\mathrm{X}-\mathrm{Mt}^{\mathrm{x}+1} / \mathrm{L}$ and $\mathrm{Mt}^{\mathrm{x}} / \mathrm{L}$ species, see equations 1 and 2 where $[I]_{0}$ is the initial concentration of the molecular halide initiator, $[\mathrm{M}]$ is the monomer concentration, $\mathrm{DP}_{\mathrm{n}}$ is the instantaneous degree of polymerisation and $p$ is the conversion. ${ }^{42}$ Hence, the polymerisation rate is unaltered if the total metal concentration is reduced while maintaining the same $\left[\mathrm{Mt}^{\mathrm{x}} / \mathrm{L}\right] /\left[\mathrm{X}-\mathrm{Mt} \mathrm{t}^{\mathrm{x}+1} / \mathrm{L}\right]$ ratio (equation 1). However, reducing the amount of metal negatively affects the polymer dispersity (equation 2). An associated problem is that irreversible termination reactions convert $\mathrm{Mt}^{\mathrm{x}} / \mathrm{L}$ into $\mathrm{X}-\mathrm{Mt}^{\mathrm{x}+1} / \mathrm{L}$ and thus the polymerisation slows down and may even stop when an insufficient amount of catalyst is used. This problem is overcome by reducing $\mathrm{X}-\mathrm{Mt}^{\mathrm{x}+1} / \mathrm{L}$ back to the ATRP catalyst $\mathrm{Mt}^{\mathrm{x}} / \mathrm{L}$ during the polymerisation process (Figure 5). 


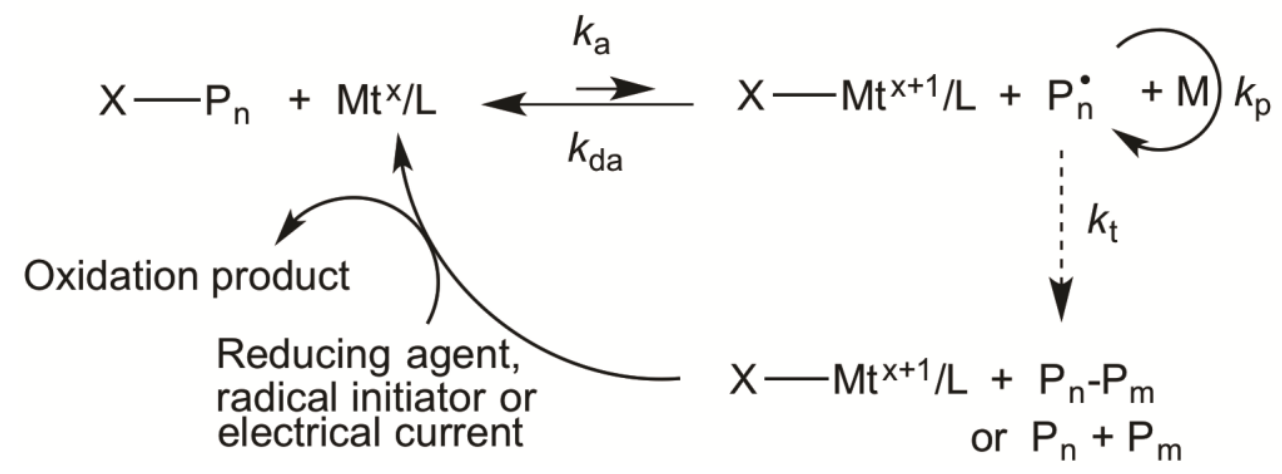

Figure 5. General scheme allowing ATRP processes to be carried out with ppm amounts of metal complex.

Different ways to accomplish such catalyst regeneration include the use of soluble reducing agents in the "Activator ReGenerated by Electron Transfer" (ARGETATRP) approach, ${ }^{43}$ conventional radical initiators such as AIBN in the "Initiators for Continuous Activator Regeneration" (ICAR-ATRP) approach, ${ }^{43,44}$ the zero-valent metal (e.g. $\mathrm{Cu}^{0}$ when using $\mathrm{Cu}^{\mathrm{I}}$ complexes as catalysts) in the "Supplemental Activator and Reducing Agent" (SARA-ATRP) approach, ${ }^{45}$ or a cathodic current in the "Electrochemical" (eATRP) approach. ${ }^{46}$ In these ways, controlled polymerisations have been achieved with concentrations as low as a few ppm of copper while

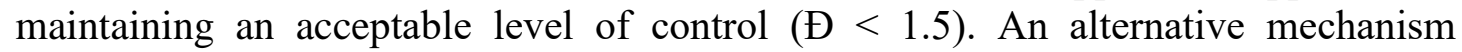
explaining the efficient polymerisation under SARA-ATRP conditions, known as "Single Electron Transfer - Living Radical Polymerisation" (SET-LRP), ${ }^{47}$ has been recently challenged. ${ }^{48}$

A complementary strategy to minimise the use of copper in ATRP is to expand the scope of metal mediators, with an array of metals containing accessible 1e- redox couples showing activity in ATRP. To this end Ti, V, Cr, Mo, Mn, Re, Fe, Ru, Os, $\mathrm{Co}, \mathrm{Rh}, \mathrm{Ni}$ and Pd among the transition metals and $\mathrm{Ge}, \mathrm{Sn}, \mathrm{Sb}, \mathrm{Bi}$ and Te among the main group metals have shown utility in RDRP. ${ }^{12,23-25,27,49,50}$ Of these, iron presents arguably the most intriguing family of catalyst. From an industrial perspective, iron is inexpensive (Fe: \$0.14 USD/kg; Cu: \$7.50 USD/kg) and non-toxic (LD50, oral $\left.\mathrm{FeSO}_{4}\left(\mathrm{H}_{2} \mathrm{O}\right)_{7}: 1520 \mathrm{mg} / \mathrm{kg} ; \mathrm{CuSO}_{4}\left(\mathrm{H}_{2} \mathrm{O}\right)_{5}: 300 \mathrm{mg} / \mathrm{kg}\right)$, although concerns for ligand toxicity remain. From an academic perspective, iron is involved in both atom transfer and organometallic equilibria. Building from a robust history of iron coordination chemistry, iron has proven to be a true competitor for copper-mediated radical polymerisations.

This comprehensive review examines the utility of iron complexes in ATRP and OMRP, discusses the array of ligands used to mediate these reactions and investigates the mechanism of action of these systems to serve as a foundation for future research in Fe-mediated reversible deactivation radical polymerisation. The first half of this review focuses on the ligands, complexes and conditions used and is meant to be comprehensive rather than prescriptive. The second half of this manuscript discusses 
the mechanistic interplay and complexity of iron-mediated RDRP and attempts to draw conclusions and trends from past efforts.

\section{Early Years (1997-1999)}

The first reports of iron-mediated reversible deactivation radical polymerisation emerged from the same pioneering groups that developed ATRP.

In 1997 Sawamoto reported the polymerisation of methyl methacrylate (MMA) using $\mathrm{FeCl}_{2}\left(\mathrm{PPh}_{3}\right)_{2}$ (Figure 6) as the catalyst and $\mathrm{CCl}_{4}$ and other organohalides as the initiator. This complex was moderately effective at controlling the polymerisation both in the absence and presence of $\mathrm{Al}\left(\mathrm{O}^{\mathrm{i}} \mathrm{Pr}\right)_{3}$. In the absence of the Lewis acid, dispersities were low (1.3-1.5) and molecular weights correlated to the excess of organohalide initiator added in to the reaction. The aluminium Lewis acid additive was postulated to act as an activator, significantly increasing the observed polymerisation rates but decreasing the control over the polymerisation, resulting in broad dispersities and molecular weights which decreased with conversion. ${ }^{51}$ This is in congruence with the rationalisation of the accelerating affect in other metalmediated RDRPs. ${ }^{52}$

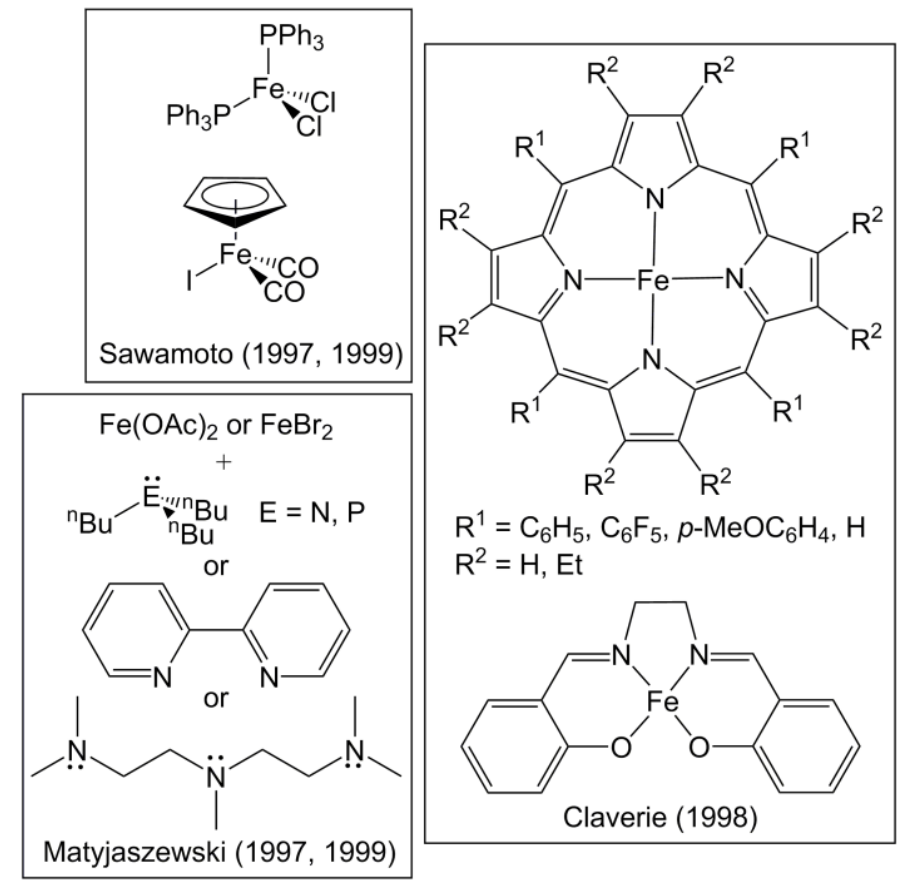

Figure 6. Early systems used in Fe-mediated reversible deactivation radical polymerisation.

Later that same year, Matyjaszewski reported the polymerisation of styrene and methyl methacrylate by $\mathrm{RX} / \mathrm{FeBr}_{2} /$ ligand initiating systems that included $\mathrm{P}\left({ }^{\mathrm{n}} \mathrm{Bu}\right)_{3}$, $\mathrm{N}\left({ }^{\mathrm{n}} \mathrm{Bu}\right)_{3}$ and bipyridine derivatives. Control over molecular weight and dispersity was excellent, with $Đ$ ranging from 1.1-1.5. Ligands, and combinations of ligands, had a strong effect on the observed polymerisation rates, with more electron-rich systems promoting rapid monomer conversion and lower dispersities. ${ }^{53}$ 
Arguably one of the most unusual and overlooked reports on Fe-mediated RDRP is an un-refereed research disclosure by Claverie, published in $1998 .^{54} \mathrm{He}$ reported an unconventional study on the role of multi-dentate ligand supported iron complexes in controlled radical polymerisation. Claverie showed that although iron(II) porphyrin and iron(II) salen complexes (Figure 6) were promising traps for organic radicals, suggestive of an organometallic mediated radical polymerisation, they were incapable of controlling polymer molecular weights or accessing high conversion, low dispersity products. Reactions could be conducted using unstable $\mathrm{Fe}^{\mathrm{II}}$ complexes and AIBN as the radical source, although radical generation from the decomposition of AIBN was slow at the reported reaction temperature of $80{ }^{\circ} \mathrm{C}$. Alternative conditions utilised the $\mathrm{Fe}^{\mathrm{III}}$ halide complex and a Grignard reagent to prepare $\mathrm{Fe}^{\mathrm{III}}-\mathrm{R}$ complexes in situ. In addition, Claverie explored these systems under a unique initiation mechanism, incorporating variable amounts of ATRP initiator 1-phenylethylbromide (1-PEBr, 10 equiv.) and the AIBN radical source (0.33-3.3 equiv.) relative to catalyst, masking radicals with both halogens and metal complex to achieve good control $(1.1 \leq$

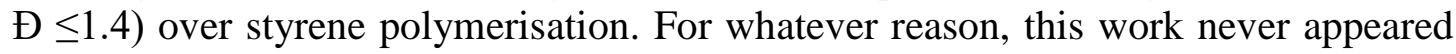
in a peer-reviewed journal nor was it followed up with a more thorough study.

The first report of iron-mediated R-ATRP soon followed in 1998. Teyssié reported on the R-ATRP of methyl methacrylate using $\mathrm{FeCl}_{3}$ and AIBN in the presence of triphenylphosphine. Dispersities were low $(<1.3)$ and while $\mathrm{M}_{\mathrm{n}}$ did not increase linearly with conversion, chain extension experiments suggested a living polymerisation. Interestingly, the report postulated that two equivalents of $\mathrm{Fe}^{\mathrm{III}}$ were needed to effectively trap each radical, suggesting an inefficiency not present in standard ATRP. 55

Breakthroughs continued in 1999, with Matyjaszewski reporting the Fe-mediated polymerisation of vinyl acetate, affording poly(vinyl acetate) with broadened dispersities (>1.8) which could be used as macroinitiators for the formation of block copolymers using copper-mediated ATRP. The vinyl acetate polymerisation, mediated by $\mathrm{Fe}(\mathrm{OAc})_{2} / \mathrm{PMDETA} / \mathrm{CCl}_{4}$, was shown to not follow an ATRP mechanism but was instead a redox-initiated radical telomerization, illustrating the challenge of mechanistic understanding before attributing behaviour to reversible deactivation radical polymerisation. ${ }^{56,57}$ Sawamoto also expanded on his initial work, introducing $\mathrm{FeCp}(\mathrm{CO})_{2} \mathrm{I}$ as a phosphine-free mediator for the RDRP of styrene. Control was only achieved when Lewis acidic titanium or aluminium alkoxides were included in the reaction mixture, significantly decreasing the polymerisation rates. Initiation by alkyl iodides afforded iodine-terminated polymer chains with surprisingly low dispersities (ca. 1.1) but the mechanistic interplay between iodine, iron and the Lewis acid remained unexplained. ${ }^{58}$

The potential of this early work inspired many groups to explore the use of iron in reversible deactivation radical polymerisations. As an easy categorisation to allow comprehensive coverage of work in this area we have separated efforts based upon the ligands employed, ordered by the frequency of their use. While references provided are comprehensive, data presented are selected from representative manuscripts or estimated from graphical representations of data provided in these references and are not meant to be comprehensive. Selected systems of mechanistic interest or importance are subsequently discussed in more detail. 


\section{Use of Iron Complexes in Reversible Deactivation Radical Polymerisation}

\section{1. Phosphine Ligands}

Phosphine ligands are the most extensively utilised ligand framework in Fe-mediated reversible deactivation radical polymerisation. Monodentate phosphines used as ligands include: triphenylphosphine, $\mathrm{PPh}_{3},{ }^{51,55,59-106}$ tri( $n$-butyl)phosphine, $\mathrm{P}^{\mathrm{n}} \mathrm{Bu}_{3},{ }^{77,83,88,101,105-107}$ tri( $t$-butyl)phosphine, $\mathrm{P}^{\mathrm{t}} \mathrm{Bu}_{3},{ }^{105}$ tricyclohexylphosphine, $\mathrm{PCy}_{3}{ }^{106}$ and methyldiphenylphosphine, $\mathrm{PPh}_{2} \mathrm{Me} .{ }^{77}$ Other strongly electron-donating monodentate phosphines have also been studied, including (4-(N,N-dimethylamino)phenyl)diphenylphosphine, $\quad \mathrm{Ph}_{2} \mathrm{P}\left(\mathrm{Me}_{2} \mathrm{NPh}\right){ }^{106}$ tris(4-polyethyleneglycolphenyl)phosphine, $\mathrm{P}(\mathrm{PEGPh}) 3{ }_{3}{ }^{106}$ tris(4-methoxyphenyl)phosphine, $\mathrm{TMPP}^{99,106}$ and tris(2,4,6trimethoxyphenyl)phosphine, TTMPP. ${ }^{99}$ Bidentate frameworks include: bis(diphenylphosphino)methane, DPPM ${ }^{83}$ bis(diphenylphosphino)ethane, DPPE, ${ }^{83}$ bis(diphenylphosphino)propane, DPPP, ${ }^{80,83,108}$ bis(diphenylphosphino)dimethylxanthene, DPPDMX ${ }^{82}$ and the mixed donor systems: 2-(diphenylphosphino)pyridine, DPPPy, ${ }^{82-}$ 84,88,101,109-111 2-[(diphenylphosphino)methyl]pyridine, DPPMPy, ${ }^{82,109,111}$ 2-(diphenylphosphino)benzaldehyde, DPPB ${ }^{82,88}$ diphenyl-(2-methoxyphenyl)phosphine, DPMPP ${ }^{88}$ (diphenylphosphino)-N,N'-dimethyl(1,1-biphenyl)-2-amine, DPPDMA, ${ }^{82,88} \mathrm{~N}$-(2-diphenylphosphinobenzylidene)aniline, DPPBA, ${ }^{82} \mathrm{~N}, \mathrm{~N}$-dimethyl-(2-(diphenylphosphino)phenyl)methanamine, DMDPM, ${ }^{80}$ N,N-dimethyl-2(dicyclohexylphosphino)phenyl)methanamine, DMDCM ${ }^{80}$ and N,N-dimethyl-1-(2(diphenylphosphino)phenyl)ethanamine, DMDPE. ${ }^{80}$ While most manuscripts detail the testing of various phosphines as supporting ligands, other reports include the effect of inhibitors ${ }^{73}$ or additives ${ }^{51,78}$ on ATRP performance and the role Fe has to play in more advanced RDRP processes (vide supra). Through studying all of these reports the most striking observation is how few trends exist. A pair of excellent recent reports suggest that electron-rich phosphines correlate with higher observed polymerization rates, and these donating phosphines may thus be the preferred choice for simple acrylate polymerizations. There are no notable relationships between catalyst performance and chelation or additives for phosphine ligands. While most perform capably well, few systems compete with the performance of copper alternatives.

Representative polymerisation data and conditions are gathered in Table 1 and phosphine ligands used are shown in Figure 7. 
Table 1. Representative Phosphine-ligated Fe-mediated ATRP

\begin{tabular}{|c|c|c|c|c|c|c|c|c|c|c|c|}
\hline Ligand & Complex & Monomer & Initiator & Solvent & $\begin{array}{l}\text { Temp / } \\
{ }^{\circ} \mathbf{C}\end{array}$ & $\begin{array}{l}\text { Time } \\
\text { / h }\end{array}$ & $\begin{array}{l}\% \\
\text { Conv }\end{array}$ & $M_{n, t h}$ & $M_{n, \exp }$ & Đ & Ref \\
\hline $\mathrm{PPh}_{3}$ & $\mathrm{FeCl}_{3}$ & Styrene & AIBN & bulk & 100 & 19 & 89 & 15,300 & 5,400 & 1.44 & 62 \\
\hline $\mathrm{PPh}_{3}$ & $\mathrm{FeCl}_{3}$ & MMA & none & bulk & 80 & 0.5 & 42 & 4,200 & 10,500 & 1.23 & 101 \\
\hline $\mathrm{PPh}_{3}$ & $\mathrm{FeCl}_{3}$ & Styrene & none & bulk & 110 & 20 & 58 & 6,100 & 6,700 & 1.55 & 101 \\
\hline $\mathrm{PPh}_{3}$ & $\mathrm{FeCl}_{3}$ & MMA & TD & bulk & 100 & 1 & 100 & 25,000 & 28,400 & 1.15 & $60,63,69$ \\
\hline $\mathrm{PPh}_{3}$ & $\mathrm{FeCl}_{3}$ & AN & DCDPS & bulk & 70 & 20 & 37 & 4,900 & 4,950 & 1.25 & 74 \\
\hline $\mathrm{PPh}_{3}$ & $\mathrm{FeCl}_{3}$ & MMA & $\mathrm{Fe}(\mathrm{dtc})_{3}$ & bulk & 80 & 1 & 80 & 7,800 & 7,200 & 1.16 & 61 \\
\hline $\mathrm{PPh}_{3}$ & $\mathrm{MCl}_{2} / \mathrm{FeCl}_{3}$ & MMA & EBrB & $\mathrm{DMF}$ & 90 & 7 & 80 & 8,300 & 8,100 & 1.28 & 72 \\
\hline $\mathrm{P}^{\mathrm{n}} \mathrm{Bu}_{3}$ & $\mathrm{FeCl}_{3}$ & Styrene & $\mathrm{R}^{1} \mathrm{Cl}$ & toluene & 100 & 528 & 91 & 9,500 & 11,100 & 1.19 & 107 \\
\hline $\mathrm{P}^{\mathrm{n}} \mathrm{Bu}_{3}$ & $\mathrm{FeBr}_{2}$ & MMA & $\mathrm{R}^{1} \mathrm{Cl}$ & toluene & 60 & 36 & 90 & 9,000 & 11,800 & 1.20 & 77 \\
\hline DPPM & $\mathrm{FeBr}_{3}$ & MMA & $\mathrm{EBrB}$ & toluene & 80 & 2 & 75 & 15,200 & 18,100 & 1.26 & 83 \\
\hline DPPM & $\mathrm{FeBr}_{2}$ & MMA & $\mathrm{EBrB}$ & toluene & 80 & 2 & 83 & 16,700 & 31,700 & 1.59 & 83 \\
\hline DPPE & $\mathrm{FeBr}_{3}$ & MMA & EBrB & toluene & 80 & 8 & 72 & 14,500 & 27,000 & 1.61 & 83 \\
\hline DPPP & $\mathrm{FeBr}_{3}$ & MMA & EBrB & toluene & 80 & 4 & 72 & 14,500 & 29,300 & 1.77 & 83 \\
\hline $\mathrm{PMePh}_{2}$ & $\mathrm{FeCl}_{2}$ & MMA & $\mathrm{R}^{1} \mathrm{Cl}$ & toluene & 80 & 13 & 91 & 15,400 & 14,300 & 1.61 & 77 \\
\hline $\mathrm{PMePh}_{2}$ & $\mathrm{FeBr}_{2}$ & MMA & $\mathrm{R}^{1} \mathrm{Br}$ & toluene & 80 & 12 & 90 & 9,000 & 11,400 & 1.31 & 77 \\
\hline DPPPy & $\mathrm{FeCl}_{3}$ & MMA & $\mathrm{EBrB}$ & toluene & 80 & 8 & 76 & 15,350 & 14,500 & 1.26 & 82,84 \\
\hline DPPPy & $\mathrm{FeCl}_{2}$ & Styrene & $\mathrm{PECl}$ & bulk & 110 & 9 & 66 & 6,900 & 8,500 & 1.36 & 109 \\
\hline DPPPy & $\mathrm{FeBr}_{2}$ & MMA & $\mathrm{EBrB}$ & p-xylene & 80 & 5 & 65 & 13,200 & 13,100 & 1.33 & 109,110 \\
\hline DPPMPy & $\mathrm{FeBr}_{2}$ & MMA & $\mathrm{EBrB}$ & p-xylene & 80 & 4 & 63 & 12,900 & 14,500 & 1.56 & 109 \\
\hline DPPMPy & $\mathrm{FeBr}_{2} / \mathrm{FeBr}_{3}$ & MMA & $\mathrm{EBrB}$ & toluene & 80 & 4 & 76 & 15,400 & 15,500 & 1.36 & 111 \\
\hline DMDPE & $\mathrm{FeBr}_{2} / \mathrm{Al}\left(\mathrm{O}^{\mathrm{i}} \mathrm{Pr}\right)_{3}$ & Styrene & $\mathrm{R}^{1} \mathrm{Br}$ & toluene & 100 & 140 & 93 & 9,700 & 10,700 & 1.30 & 80 \\
\hline
\end{tabular}

Table acronyms: TD = tetraethylthiuram disulfide; DCDPS = diethyl 2,3,-dicyano-2,3,-diphenylsuccinate; dtc = tri(diethyldithiocarbamate); $\mathrm{R}^{1} \mathrm{X}$ $=\mathrm{Me}_{2} \mathrm{C}\left(\mathrm{CO}_{2} \mathrm{Me}\right) \mathrm{CH}_{2} \mathrm{C}\left(\mathrm{CO}_{2} \mathrm{Me}\right)(\mathrm{Me}) \mathrm{X}, \mathrm{X}=\mathrm{Cl}$ or $\mathrm{Br} ; \mathrm{DPPX}=$ bis(diphenylphosphino)methane, ethane and propane; DPPPy = diphenylphosphinopyridine; DPPMP = diphenylphosphinomethylpyridine; DMDPE = dimethyl (diphenylphosphino)phenyl)-ethanamine; $\mathrm{M}=$ $\mathrm{Ni}, \mathrm{Co}, \mathrm{Sn}, \mathrm{Mn} ; \mathrm{MMA}=$ methyl methacrylate; $\mathrm{AN}=$ acrylonitrile; $\mathrm{AIBN}=$ azobis(isobutyronitrile); $\mathrm{EBrB}=$ ethyl bromoisobutyrate; $\mathrm{PECl}=1$ phenylethylchloride; DMF = dimethylformamide. 


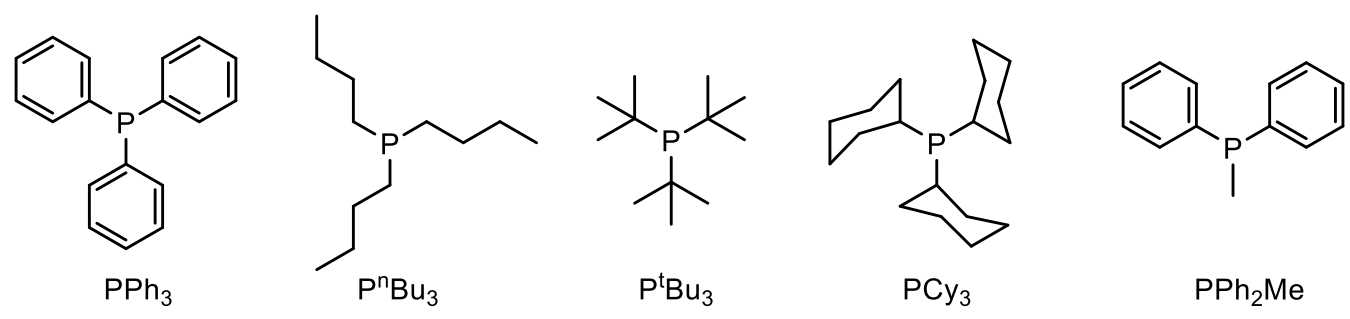

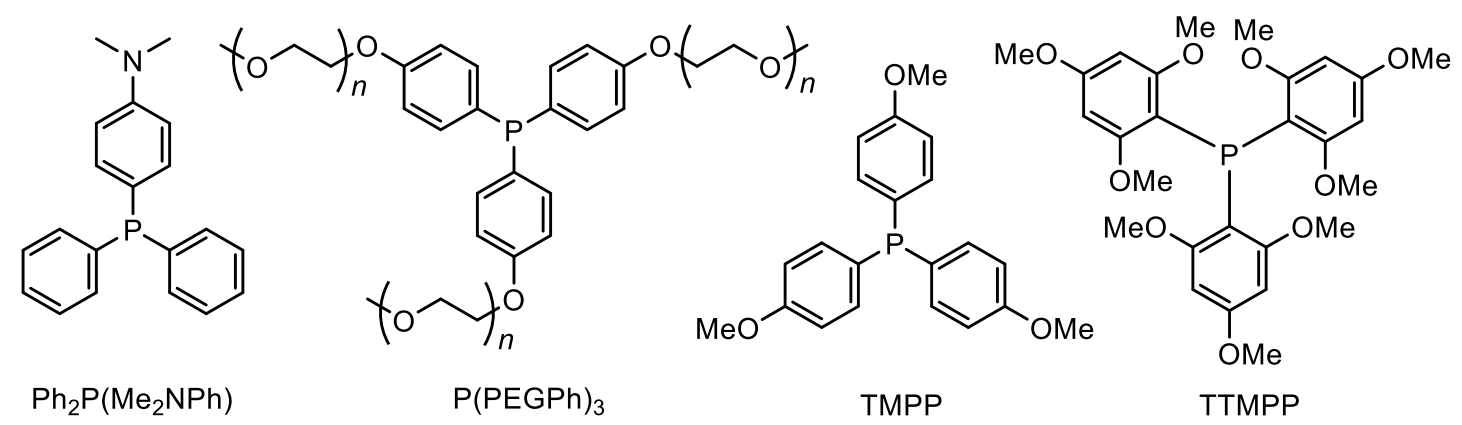<smiles>PP(CP(c1ccccc1)c1ccccc1)c1ccccc1</smiles><smiles>c1ccc(P(CCP(c2ccccc2)c2ccccc2)c2ccccc2)cc1</smiles><smiles>c1ccc(P(CCCP(c2ccccc2)c2ccccc2)c2ccccc2)cc1</smiles><smiles>CC1(C)c2cccc(P(c3ccccc3)c3ccccc3)c2Oc2c(P(c3ccccc3)c3ccccc3)cccc21</smiles>

DPPM

DPPE

DPPP

DPPDMX<smiles>c1ccc(-c2ccccn2)cc1</smiles><smiles>c1ccc(Cc2ccccn2)cc1</smiles><smiles>O=Cc1ccccc1Pc1ccccc1</smiles><smiles>COc1ccccc1Pc1ccccc1</smiles><smiles>CN(C)c1ccccc1-c1ccccc1P</smiles>

DPPPy

DPPMPy

DPPB

DPMPP

DPPDMA<smiles>C(=[PH+]c1ccccc1)c1ccccc1Pc1ccccc1</smiles>

DPPBA<smiles>CN(Cc1ccccc1)c1ccccc1-c1ccccc1</smiles>

DMDPM<smiles>CCCCc1ccccc1CN(C)C</smiles>

DMDCM<smiles>CC(C)c1ccccc1Pc1ccccc1</smiles>

DMDPE

Figure 7. Structural formulas of phosphine ligands used in combination with $\mathrm{Fe}$ in ATRP.

\subsection{Imine Ligands}

While most work with phosphine ligands focused on the addition of an external ligand additive to the polymerisation reaction, the influx of work using $\alpha$-diimine ligands began to move the focus onto the activity of isolable metal complexes to serve as mediators of reversible deactivation radical polymerisation. Early work on diimine frameworks ${ }^{39,112,113}$ was extended to iminopyridines ${ }^{114-119}$ and thus pyridine systems are included here as a closely related functionality for simplicity. Bipyridine ligands are a well-studied class in themselves and have been used in iron-mediated 
ATRP, ${ }^{53,96,120-129}$ with optimal polymerisation conditions determined using highthroughput methodologies. ${ }^{123}$ Isolated complexes used to support Fe-mediated RDRP are shown in Figure 8 and representative data are collected in Table 2. Two top performers are noted in this class of ligands: the [ $\alpha$-diimine] $\mathrm{FeCl}_{2}$ complexes, especially those with the electron-donating $p$-NMe ${ }_{2} \mathrm{Ar}$ substituents, function well for the ATRP of styrenes while the salicylaldiminato $\mathrm{Fe}^{\mathrm{III}}$ complexes are excellent catalyst precursors for R-ATRP. Further details are provided in Sections 4.6 and 4.7.

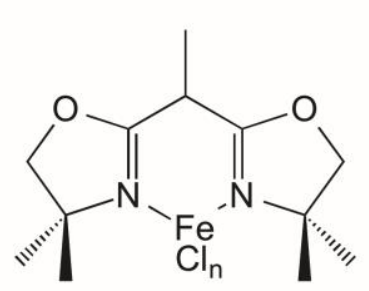

[box] $\mathrm{FeCl}_{n}$ $\mathrm{n}=2,3$<smiles></smiles>
$\mathrm{Cl} \mathrm{Cl}$

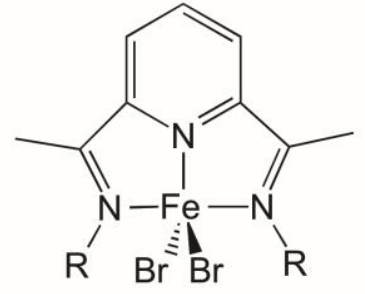

[bimpy] $\mathrm{FeBr}_{2}$

$\mathrm{R}=$ octyl, 2,6- $\mathrm{Pr}_{2} \mathrm{C}_{6} \mathrm{H}_{3}$<smiles></smiles>

$\mathrm{R} 1, \mathrm{R} 2[\mathrm{NN}] \mathrm{FeCl}_{2}$

$\mathrm{R}^{1}=\mathrm{tBu}, \mathrm{Cy}, \mathrm{c}-\mathrm{C}_{12} \mathrm{H}_{23}, \mathrm{Ad}, \mathrm{iPr}, \mathrm{tBu}, 2,6-\mathrm{Pr}_{2} \mathrm{C}_{6} \mathrm{H}_{3}$

$\mathrm{R}^{2}=\mathrm{H}, \mathrm{Me}, p-\mathrm{XC}_{6} \mathrm{H}_{4} ; \mathrm{X}=\mathrm{H}, \mathrm{Me}, \mathrm{F}, \mathrm{OMe}, \mathrm{NMe}_{2}$<smiles>[R]C1=CC=CC2=C([Ge](Cl)(Cl)Cl)N([R])[Ge](Cl)(Cl)N12</smiles>

[impy] $\mathrm{FeCl}_{2}$

$\mathrm{R}^{1}=\mathrm{nPr}, \mathrm{c}-\mathrm{C}_{12} \mathrm{H}_{23}$,

$$
\text { Cy, 2,6-i }-\mathrm{Pr}_{2} \mathrm{C}_{6} \mathrm{H}_{3}
$$

$\mathrm{tBu}$<smiles>Cc1cc(/C=N\N(C)c2cccc3cccnc23)c(OCCl)c(C(C)(C)C)c1</smiles>

[salaldim] $\mathrm{FeCl}$

$\mathrm{R}^{2}=\mathrm{H}, \mathrm{Me}$

Figure 8. Imine complexes used in ATRP. Note: Imines added in as external ligands only are not included. 
Table 2. Representative Imine-ligated Fe-mediated ATRP

\begin{tabular}{|c|c|c|c|c|c|c|c|c|c|c|}
\hline Complex & Monomer & Initiator & Solvent & $\begin{array}{l}\text { Temp / } \\
{ }^{\circ} \mathrm{C}\end{array}$ & $\begin{array}{l}\text { Time } \\
/ / \mathbf{h}\end{array}$ & $\begin{array}{l}\% \\
\text { Conv }\end{array}$ & $M_{n, t h}$ & $\mathbf{M}_{n, \exp }$ & $\boldsymbol{\oplus}$ & Ref \\
\hline$[$ box $] \mathrm{FeCl}_{2}$ & Styrene & 1-PEBr & toluene & 120 & 24 & 55 & 11,500 & 3,100 & 1.40 & 130 \\
\hline$[\mathrm{box}] \mathrm{FeCl}_{3}$ & Styrene & TPED & toluene & 120 & 20 & 60 & 6,200 & 5,200 & 1.20 & 126,130 \\
\hline [bimpy] $\mathrm{FeBr}_{2}$ & MMA & 1-PEBr & anisole & 90 & 9 & 42 & 8,400 & 6,000 & 1.68 & $114,116,119$ \\
\hline$\left[{ }^{\mathrm{Cy}}[\mathrm{NN}] \mathrm{FeCl}\right]_{2}(\mu-\mathrm{Cl})_{2}$ & Styrene & 1-PECl & bulk & 120 & 20 & 50 & 10,400 & 87,400 & 1.53 & 131 \\
\hline${ }^{\mathrm{R}}[\mathrm{NN}] \mathrm{FeCl}_{2}{ }^{\mathrm{a}}$ & Styrene & 1-PECl & bulk & 120 & 24 & 96 & 20,200 & 20,600 & 1.27 & $112,113,132$ \\
\left.\hline${\mathrm{R}, \mathrm{R}^{\prime}}^{\prime} \mathrm{NN}\right] \mathrm{FeCl}_{2}{ }^{\mathrm{b}}$ & Styrene & 1-PECl & bulk & 120 & 0.4 & 62 & 12,900 & 9,400 & 1.20 & $39,132-134$ \\
\hline${ }^{\mathrm{dtd}}$ bipy/FeBr 2 & MMA & $\mathrm{EBrB}$ & p-xylene & 90 & 4.7 & 50 & 7,650 & 10,570 & 1.28 & 123 \\
\hline bipy/FeBr 3 & StMA & $\mathrm{AIBN} / \mathrm{CBr}_{4}$ & $\mathrm{DMF}$ & 80 & 2 & 64 & 7,200 & 6,600 & 1.51 & 121 \\
\hline$[\mathrm{impy}] \mathrm{FeCl}_{2}$ & Styrene & 1-PECl & bulk & 120 & 24 & 100 & 19,000 & 18,400 & 1.34 & 115 \\
\hline$[\mathrm{impy}] / \mathrm{FeBr}_{2} / \mathrm{FeCl}_{3}$ & MMA & $\mathrm{EBrB}$ & 2-butanone & 90 & 7 & 84 & 12,800 & 16,500 & 1.26 & 117,118 \\
\hline [salaldim] $\mathrm{FeCl}_{2}$ & Styrene & 1-PEBr & bulk & 120 & 1.2 & 78 & 8,100 & 7,900 & 1.08 & 135 \\
\hline
\end{tabular}

${ }^{\mathrm{a}} \mathrm{R}={ }^{\mathrm{t}} \mathrm{Bu}, \mathrm{Cy}, c-\mathrm{C}_{12} \mathrm{H}_{23}, \mathrm{Ad},{ }^{\mathrm{i}} \mathrm{Pr},{ }^{\mathrm{t}} \mathrm{Bu}$, DiPP; data presented for $\mathrm{R}=\mathrm{Cy}$

${ }^{\mathrm{b}} \mathrm{R}=\mathrm{Cy}$, 'Bu, DiPP; R' = H, Me, Ph, NMe ${ }_{2} \mathrm{Ph}, \mathrm{MeOPh}, \mathrm{MePh}, \mathrm{FPh}$; data presented for $\mathrm{R}=\mathrm{Cy}, \mathrm{R}$ ' $=\mathrm{NMe} 2 \mathrm{Ph}$

StMA = stearyl methacrylate

bipy $=2,2$ '-bipyridine

$\operatorname{dtd}=\operatorname{di}($ tridecanyl $)$

TPED = 1,1,2,2-tetraphenyl-1,2-ethanediol 


\subsection{Amine Ligands}

Although multidentate amine ligands are prolific as supports for copper-mediated reversible deactivation radical polymerisation, their use in Fe-mediated RDRP is much more limited. While multidentate frameworks featuring amines alongside other more prominent donors have been featured, ${ }^{54,80,82,114-116,135}$ other amine donors used in RDRP include: tri(n-butyl)amine, $\mathrm{N}^{\mathrm{n}} \mathrm{Bu}_{3}{ }^{53,80,105,120,136}$ and derivatives $\mathrm{HN}^{\mathrm{n}} \mathrm{Bu}_{2}$ and $\mathrm{H}_{2} \mathrm{~N}^{\mathrm{B}} \mathrm{Bu},{ }^{105}$ hexadecyltrimethyl amine, HTMA, ${ }^{127}$ hexamethylene tetramine, HMTA, ${ }^{137}$ tris(3,6-dioxaheptyl)amine, TDA, ${ }^{95,100,138-148}$ tetramethylethylenediamine, TMEDA, ${ }^{82,127}$ tetraethylethylenediamine, TEEDA, ${ }^{132}$ tetramethylpropane-1,3diamine, TPDA ${ }^{80}$ tetradentate bis(amine)bis(pyridine) ligands ${ }^{149}$ N,N,N',N', N', penta(methylacrylate)diethylenetriamine, MAs DETA ${ }^{150,151}$ and N,N,N',N' ,N' '-pentamethyldiethylenetriamine, PMDETA. ${ }^{56,57,96,105,152}$

Beyond simple mono- and multi-dentate amine ligands, several interesting examples of amine-supported iron complexes have been reported. The ionic iron complex $\left[\left(\mathrm{Me}_{3} \mathrm{tacn}\right)_{2} \mathrm{Fe}_{2} \mathrm{Cl}_{3}\right]\left[\left(\mathrm{Me}_{3} \mathrm{tacn}\right) \mathrm{FeCl}_{3}\right]$, where $\mathrm{Me}_{3}$ tacn is 1,4,7-trimethyltriazacyclononane), is an efficient catalyst for styrene and acrylate polymerisation, affording both block and homopolymers (Figure 9, A) ${ }^{153}$ The cation/anion pair was initially immiscible in the monomers but eventually transformed and accessed polymers with dispersities as low as 1.2. Importantly, the solubility of the catalyst precursor in methanol led to improved separation, leaving only $14 \mathrm{ppm}$ of iron in the resultant polymer whilst also permitting limited catalyst recycling. The nature of the active species and its speciation was further explored with isopropyl ligand derivatives. ${ }^{154}$

Amine-bis(phenolate) multidentate ligand frameworks accessed iron complexes of a more defined nature, preventing speciation in solution whilst raising other mechanistic questions. ${ }^{155,156}$ The $\left[\mathrm{O}_{2} \mathrm{NN}\right.$ '] FeCl complexes (Figure 9, B) were efficient mediators of the rapid and controlled polymerisation of substituted styrenes and methyl methacrylate, with dispersities as low as 1.07. Investigating the reaction, however, pointed towards a multi-mechanism system and implied control by both traditional atom-transfer and unconventional organometallic routes, as will be further elaborated in section 4.4. This system is the fastest reported for iron-based RDRP of styrenes, reaching over $90 \%$ conversion of styrene in under $2 \mathrm{~h}$.

Bio-inspired iron porphyrin complexes (Figure 9, C), based on hemin, were recently reported to act as efficient ATRP mediators under AGET conditions. ${ }^{157}$ Best results were obtained with mesohemin-MPEG, synthesised through the hydrogenation and esterification of hemin, which controlled the polymerisation of oligo(ethylene oxide) methyl ether methacrylate (OEMA) in both aqueous and organic media with $Đ$ as low as 1.19 . 

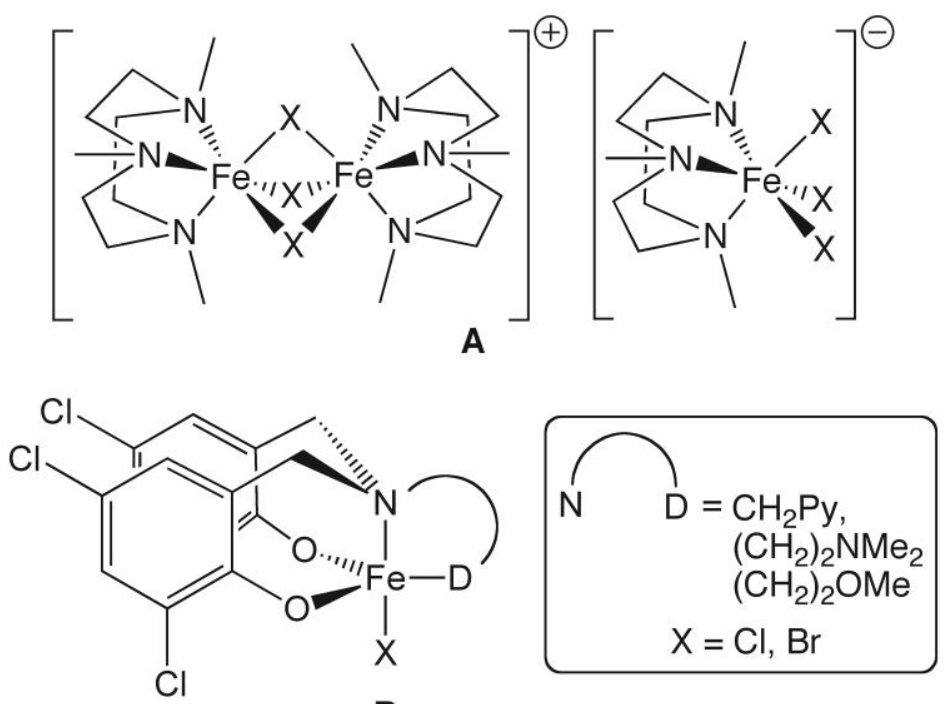

B

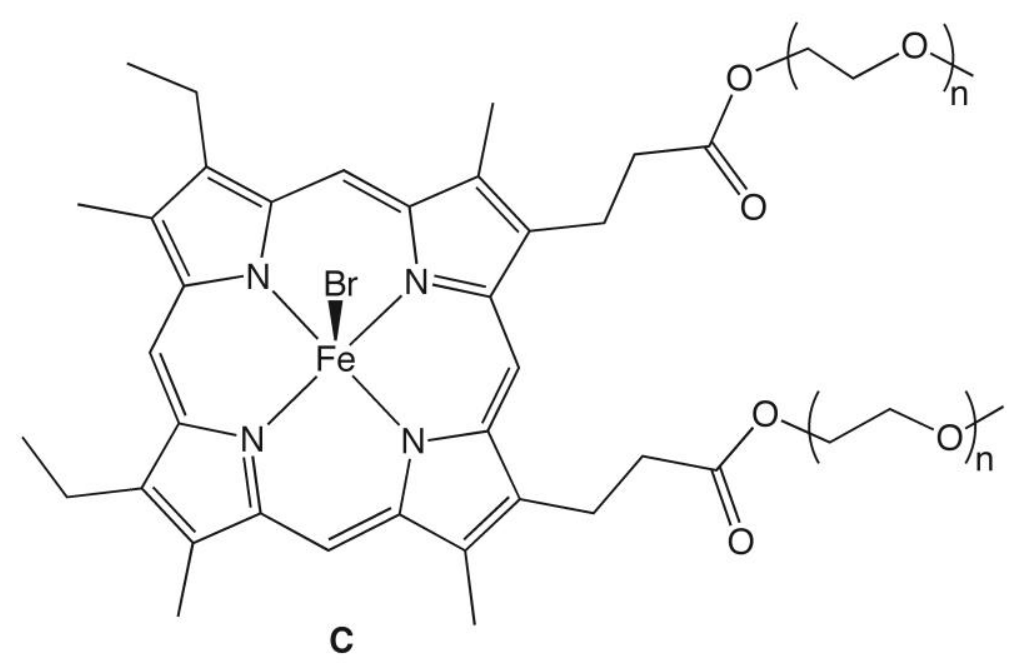

Figure 9. Selected amine ligated iron complexes for reversible deactivation radical polymerisation.

Interestingly, these two examples represent some of the exemplar iron complexes for Fe-mediated reversible deactivation radical polymerisation. Alongside the previously mentioned salicylaldimine complexes, ${ }^{135}$ these complexes feature inert covalent bonds fixing the iron to the ligand framework. With the implication that the ligands in these instances are permanent features of the coordination sphere, this would limit speciation compared to ligands whose primary role may be to solubilise the Fe salts. Importantly, these defined complexes lead to the best control and fastest rates reported thus far for iron-mediated RDRP.

\subsection{Other ligands}

Other miscellaneous classes of ligands supporting Fe-based ATRP include hexamethylphosphoric triamide (HMPTA) ${ }^{158}$ dithiocarbamates, ${ }^{159-162}$ for which the resultant iron species may need to be additionally activated by photolysis, ${ }^{159-161}$ and carbon-ligated systems including the half-metallocene $\mathrm{CpFe}(\mathrm{CO})_{2} \mathrm{X} /\left[\mathrm{CpFe}(\mathrm{CO})_{2}\right]_{2}$ complexes used by Sawamoto. ${ }^{163-168}$ Interesting, yet not fully realised, potential applications of these systems include the putative RDRP of vinyl acetate and water- 
based suspension polymerisation. ${ }^{165,168}$ Complicating this work is that the top performing system is $\mathrm{CpFe}(\mathrm{CO})_{2} \mathrm{I}$, thus the influence of iodine on the reaction as a secondary class of transfer agent cannot be discounted. ${ }^{166}$ Other carbon-based systems include ferrocene derivatives with limited efficacy ${ }^{169}$ and N-heterocyclic carbenes as highly donating, extremely efficient phosphine alternatives. ${ }^{170}$

A recent report investigated the efficacy of iron bis(acetylacetonate) for the reversible deactivation radical polymerisation of VAc, the first example of OMRP of this monomer mediated by an iron complex. ${ }^{171} \mathrm{Fe}(\mathrm{acac})_{2}$ imparted control over the polymerisation under both reversible termination (RT) and degenerative transfer (DT) conditions, with relatively narrow dispersities (1.16-1.46) obtained. Although molecular weights were somewhat higher than the theoretical values in RT-OMRP, this could be mitigated by the addition of Lewis bases to the polymerisation or by switching to the DT-OMRP regime. In both cases this was attributed to disaggregation of the catalyst, allowing the formation of mononuclear dormant species.

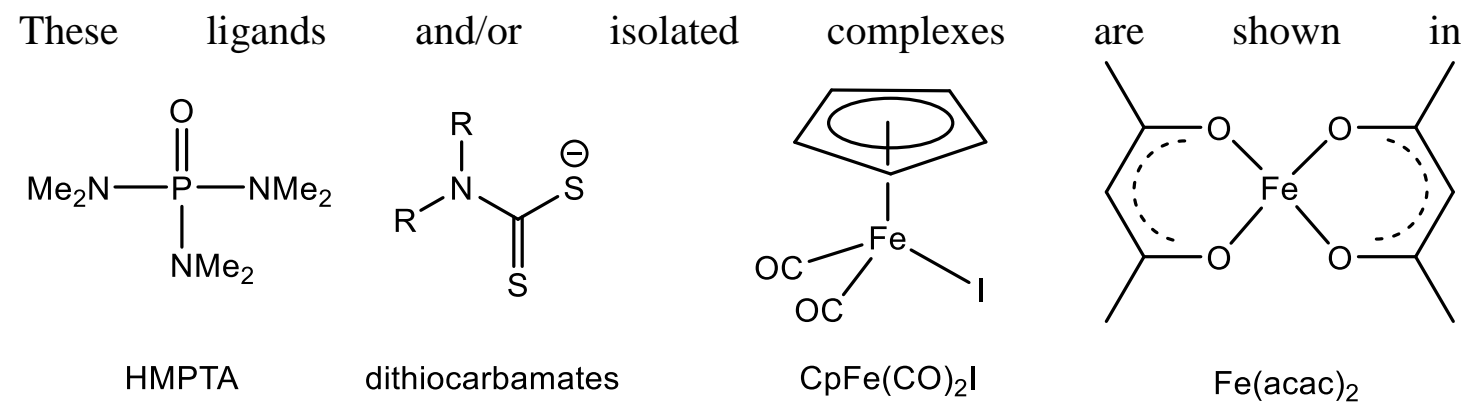

Figure 10.<smiles>COP(N)(=O)N(C)C</smiles>

HMPTA<smiles>[R]N([R])C(=S)[S-]</smiles>

dithiocarbamates<smiles>O=CP(=O)(I)c1ccccc1Cl</smiles>

$\mathrm{CpFe}(\mathrm{CO})_{2} \mathrm{I}$

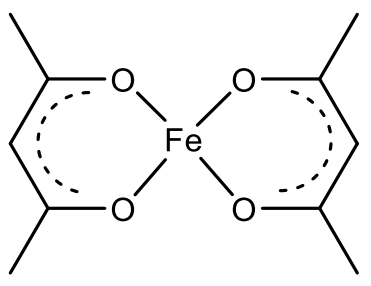

$\mathrm{Fe}(\mathrm{acac})_{2}$

Figure 10. Other miscellaneous ligands and complexes used in Fe-mediated RDRP.

\subsection{No External Ligands}

From hard amine and oxygen donors to soft phosphine and sulfur Lewis bases, an array of ligands can be used to prepare iron complexes capable of mediating radical reactions. A logical extension of this work was to use the solvent in the reaction as the ligating species, effectively creating 'ligand free' ATRP. Solvents effective as both reaction media and donors include standard ones such as NMP, DMF and MeCN, ${ }^{172-}$ 177 as well as oligomeric-length polyethers poly(ethylene glycol), poly(propylene glycol) and poly(tetrahydrofuran)s, ${ }^{178}$ although solvents that bind too strongly to iron and displace halogens, such as DMSO, are ineffective. ${ }^{172}$ This suggests a Goldilocks effect whereby the solvent, acting as ligand, has controlled the iron stability, coordination sphere and redox chemistry. A highlight of this work is the efforts to 
understand the nature of the active species in these polymerisations using VIS/NIR measurements of the RDRP of methyl methacrylate at variable pressures. ${ }^{176,177}$ This work highlighted the complexity of iron coordination chemistry and its effect on controlling radical polymerisations, suggesting that conflicting results can be obtained due to multiple active species forming through disproportionation reaction.

\subsection{Acid Additives}

The definition of the word ligand in coordination chemistry derives from the Latin root "ligare" implying binding. Many reports on ligands in Fe-mediated RDRP contain chemical functionalities that may not be simply limited to binding the metal salt but could also play an active role in the chemistry of the complex equilibria. This is particularly true for acid additives where their primary role as reported in the literature is attributed to that of a ligand, despite their established role in modifying redox chemistry and single electron reactions.

Reaction conditions utilised include acid / monomer combinations of ethylenediamine tetraacetic acid (EDTA) / styrene, ${ }^{179-181}$ ethylenediamine tetraacetic acid / ${ }^{\mathrm{n}} \mathrm{BA},{ }^{181}$ pyromellitic acid / MMA, ${ }^{182}$ iminodiacetic acid / styrene, ${ }^{183,184}$ iminodiacetic acid / MMA, ${ }^{183-185}$ iminodiacetic acid / acrylonitrile, ${ }^{186-190}$ isophthalic acid / MMA, ${ }^{96,184,191,192}$ isophthalic acid / MA, ${ }^{192}$ isophthalic acid / ${ }^{\mathrm{n}} \mathrm{BA},{ }^{192}$ isophthalic acid / acrylonitrile, ${ }^{193-197}$ isophthalic acid / methacrylonitrile, ${ }^{198}$ succinic acid / styrene, ${ }^{184,199,200}$ succinic acid / MMA, ${ }^{201}$ succinic acid / ${ }^{\mathrm{n}} \mathrm{BA},{ }^{202}$ succinic acid / acrylonitrile, ${ }^{200,203-205}$ sulfosalicylic acid / MMA, ${ }^{206}$ lactic acid / MMA, ${ }^{207}$ lactic acid / acrylonitrile, ${ }^{208}$ acetic acid / styrene ${ }^{184,209}$ acetic acid / acrylonitrile, ${ }^{210}$ and (di)picolinic acids / MMA. ${ }^{96,211}$ Copolymerisation of styrene and acrylonitrile has been reported using both succinic ${ }^{200,212}$ and isophthalic ${ }^{213}$ acids, and maleic anhydride-co-alkyl acrylamides were obtained using succinic acid as the ligand. ${ }^{214}$ Control by these systems is generally respectable $(\bigoplus$ 1.2-1.5) but varies based upon the reaction conditions employed.

Many of these reports feature similar results if operating from either a reverse-ATRP or standard ATRP protocol, suggesting that some of these acids may be capable of reducing the high-oxidation state iron in situ to access $\mathrm{Fe}^{\mathrm{II}}$ intermediates or regenerate $\mathrm{Fe}^{\mathrm{II}}$ during the course of the reaction through a similar mechanism to ARGET ATRP. This is exemplified by the explicit use of these systems, and salt additives, in ARGET, AGET and ICAR ATRP (vide infra).

\subsection{Salt Additives}

The use of a salt additive to modify RDRP equilibria and affect RDRP in iron systems was first reported by Matyjaszewski in $2000 .^{215}$ In this report, ammonium and phosphonium chloride, bromide and iodide salts were used in conjunction with iron bromide under both ATRP and reverse ATRP conditions to control the radical polymerisation of styrene, methyl methacrylate and methyl acrylate monomers. The suggestion that multiple iron products may be involved in controlling - or not controlling - these reactions was very important. The idea that speciation could play an important role in promoting, understanding and developing RDRP techniques, was an essential breakthrough for the development of this field. This seminal manuscript was largely forgotten until the recent revival in the use of salt additives in RDRP 
systems, resulting in a spate of publications. Salts utilised include: phosphazenium salts, ${ }^{216}$ ionic liquids $27,137,196,198,217-221$ and various onium salts, with both simple halide counterions ${ }^{177,215,220-230}$ and weakly coordinating anions such as triflate. ${ }^{177,224}$ The use of salts to control speciation is especially apparent in the extension to ARGET systems using ppm levels of iron, where both a reducing agent (ascorbic acid) and salt are used to moderate both the $\left[\mathrm{Fe}^{\mathrm{II}}\right] /\left[\mathrm{Fe}^{\mathrm{III}}\right]$ ratio and the nature of active species. ${ }^{225}$

\section{$\underline{\text { 3.8. Monomer and Macrostructure Scope }}$}

Figure 11 shows the breadth of monomers utilised in Fe-mediated RDRP. Methyl methacrylate and styrene are the two most commonly used monomers in ironmediated reversible deactivation radical polymerisation. While some investigation has been carried out on substituted styrenes, ${ }^{132,136,156,164}$ the (meth)acrylate monomers have been more widely explored. Simple methyl and butyl (meth)acrylate monomers including methyl acrylate, ${ }^{82,105,107,111,132,165-167,192,215,222}$ n-butyl acrylate, ${ }^{107,111,154,165,167,179,181,192,202,228}$ t-butyl acrylate, ${ }^{95,119,165,167}$ n-butyl methacrylate $^{68,71,77,82-84,149,182}$ and t-butyl methacrylate ${ }^{173}$ have been expanded to include benzyl methacrylate ${ }^{106}$ and long-chain alkyl acrylates such as stearyl methacrylate, ${ }^{121,122}$ hexadecyl methacrylate $^{128}$ and docosyl acrylate. ${ }^{125,129}$ Polymerisation of functionalised acrylates has also been achieved, with reports on the iron mediated RDRP of di(ethylene glycol) ethyl ether acrylate, ${ }^{228}$ cholic-acid modified methacrylate, ${ }^{152}$ glycidyl methacrylate, ${ }^{147}$ 2-ethoxyethyl methacrylate, ${ }^{173} 2$ hydroxyethyl methacrylate, ${ }^{89,106}$ 2-hydroxypropyl methacrylate, ${ }^{132}$ poly(ethylene glycol) monomethyl ether methacrylate, $79,85,92,98,103,106,142,144,146-148,157,216 \quad \mathrm{~N}, \mathrm{~N}-$ dimethylaminoethyl methacrylate ${ }^{79,144}$ and 2,2,2-trifluoroethyl methacrylate. ${ }^{79}$ These monomers are complemented by: acrylonitrile $74,76,186-190,193-197,200,203-205,208,210,219$ including under microwave irradiation, ${ }^{194}$ methacrylonitrile, ${ }^{198,218} \mathrm{~N}, \mathrm{~N}$ dimethylacrylamide, ${ }^{166} \mathrm{p}$-Cl styrene, ${ }^{156,164} \mathrm{p}-\mathrm{Me}$ styrene, ${ }^{136,156,164} \mathrm{p}$-tBu styrene, ${ }^{136} \mathrm{p}$ $\mathrm{MeO}$ styrene, ${ }^{132,156} \mathrm{p}$-OAc styrene, ${ }^{136,164} \mathrm{p}-\mathrm{CH}_{2} \mathrm{OAc}$ styrene, ${ }^{164}$ methyl 4vinylbenzoate, ${ }^{136}$ vinyl acetate, ${ }^{56,57,168,171}$ and 9-(4-vinylbenzyl)-9H-carbazole. ${ }^{142}$ There are no unambiguous trends observed for why certain authors chose particular monomer / iron / ligand combinations, as much of this work was exploratory; much of this advancement seems driven by particular groups exploring the scope whilst developing a particular ligand/metal combination. The performance of RDRP of these monomers is also quite variable, with high dispersities and molecular weights commonplace. It is clear that the monomer scope for iron-mediated RDRP needs much further development. 
<smiles>[R]OC(=O)C(=C)C</smiles>

$$
\begin{aligned}
\mathrm{R}= & \mathrm{CH}_{3}, \mathrm{nBu}, \mathrm{tBu}, \mathrm{CH}_{2} \mathrm{Ph},\left(\mathrm{CH}_{2}\right)_{15} \mathrm{CH}_{3}, \\
& \left(\mathrm{CH}_{2}\right)_{17} \mathrm{CH}_{3}, \mathrm{CH}_{2} \mathrm{CH}_{2} \mathrm{OH}, \\
& \mathrm{CH}_{2} \mathrm{CH}_{2} \mathrm{OCH}_{2} \mathrm{CH}_{3}, \mathrm{CH}_{2} \mathrm{CH}(\mathrm{OH}) \mathrm{CH}_{3}, \\
& \mathrm{CH}_{2} \mathrm{CH}(\mathrm{O}) \mathrm{CH}_{2},\left(\mathrm{CH}_{2} \mathrm{CH}_{2} \mathrm{O}\right)_{n} \mathrm{CH}_{3}, \\
& \mathrm{CH}_{2} \mathrm{CH}_{2} \mathrm{NMe}_{2}, \mathrm{CH}_{2} \mathrm{CF}_{3}, \\
& \left(\mathrm{CH}_{2} \mathrm{CH}_{2} \mathrm{O}\right)_{3} \mathrm{CA}(\mathrm{CA}=\text { cholic acid })
\end{aligned}
$$
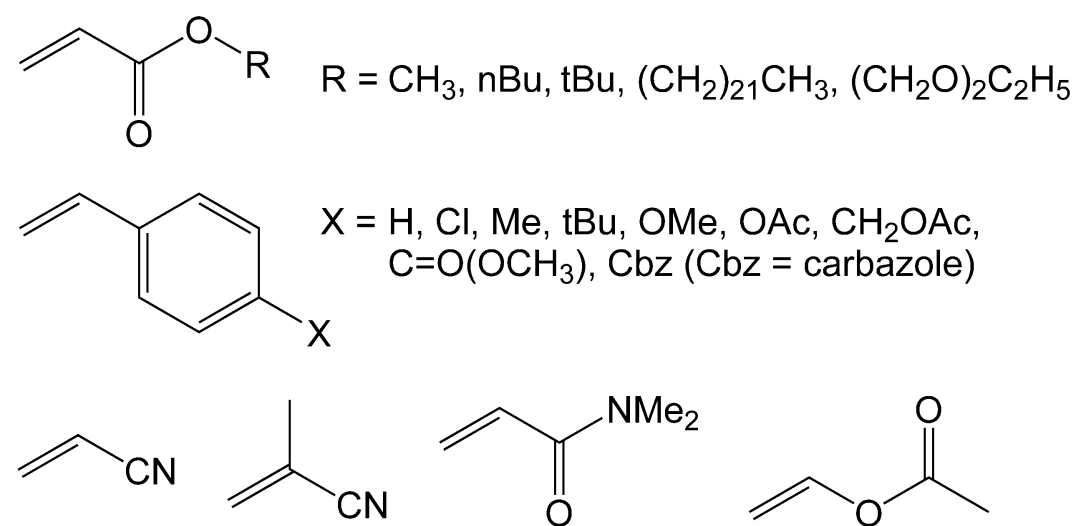<smiles>C=CC(=O)N(C)C</smiles><smiles>C=COC(C)=O</smiles>

Figure 11. Monomer scope of Fe-mediated reversible deactivation radical polymerisations.

This increased monomer scope has allowed researchers to prepare block copolymers using Fe-mediated RDRP. ${ }^{71,77,84,85,88,101,102,111,136,142,153,154,159,161,164,165,167,173,179,183,184,198}$ These reports include amphiphilic A-PEO-A triblock copolymers (A = MMA or BMA prepared from polymerizations of the A monomer from a symmetrical bis(chloro)-terminated poly(ethylene oxide) macroinitiator (Figure 12a) ${ }^{71}$ and block structures of multiple styrene derivatives. ${ }^{164} \mathrm{Fe}$-mediated RDRP has also been used to prepare polymer brushes from designed macroinitiators including polyethylene-graftand polypropylene-graft-poly(methyl methacrylates) using peroxide modified PE and PP chains as initiators for chain growth (Figure 12b). ${ }^{67,70}$ 


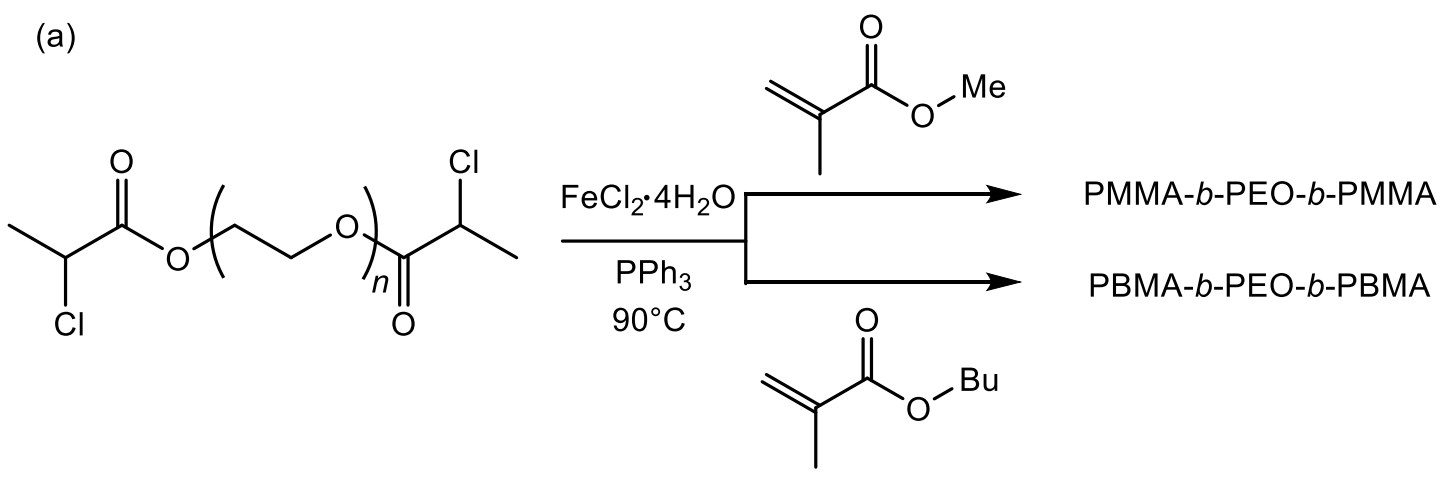

(b)

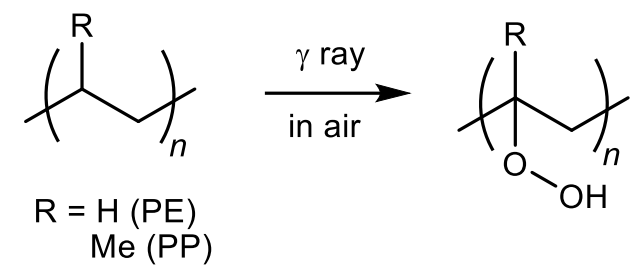

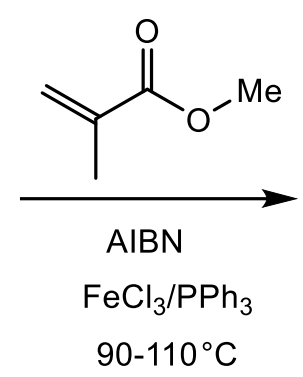

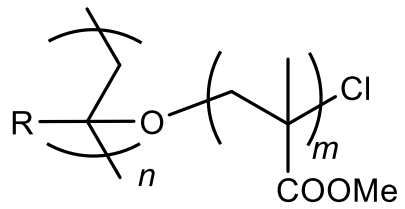

PE-graft-PMMA PP-graft-PMMA

Figure 12. Examples of macromolecular structures accessed by Fe-mediated RDRP.

\section{Mechanistic Features of RDRP with iron complexes}

This section provides considerations on the necessary conditions for Fe complexes to ensure control in RDRP and on the possible interplay between different processes.

\section{1. "Pure" ATRP processes}

An RDRP process can never really be considered to take place by a pure ATRP mechanism because the ATRP activator/catalyst $\mathrm{Mt}^{\mathrm{x}} / \mathrm{L}$, in addition to sequestering a halogen atom from the initiator/dormant chain to yield $\mathrm{X}-\mathrm{Mt}^{\mathrm{x}+1} / \mathrm{L}$, may also trap the growing radical chain $\mathrm{P}_{\mathrm{n}}{ }^{\cdot}$ to yield the RT-OMRP dormant species $\mathrm{P}_{\mathrm{n}}-\mathrm{Mt}^{\mathrm{x}+1} / \mathrm{L}^{32}$ The intervention of RT-OMRP trapping depends on the homolytic strength of the $\mathrm{Mt}^{\mathrm{x}+1}-\mathrm{C}$ bond. In most iron-mediated ATRP processes the catalyst is an $\mathrm{Fe}^{\mathrm{II}}$ complex, thereby generating a halogenated $\mathrm{Fe}^{\mathrm{III}}$ complex as the ATRP deactivator and potentially an organometallic Fe $\mathrm{FII}^{\mathrm{III}} \mathrm{RT}-\mathrm{OMRP}$ dormant species. However, if the coordination sphere around the $\mathrm{Fe}$ centre is unsuitable for stabilising the putative $\mathrm{Fe}^{\mathrm{III}}-\mathrm{C}$ bond (i.e. the resulting $\mathrm{Fe}^{\mathrm{III}}-\mathrm{C}$ bond is homolytically weak), then the RDRP process may take place via an essentially pure ATRP mechanism. For most reported RDRP reactions that were proposed to take place by a pure ATRP mechanism, simply because they were set up under ATRP or R-ATRP conditions, control experiments to verify the ability of the catalyst to trap the growing radical chains are lacking. Exceptions will be addressed below, in section 4.4 .

\subsection{Reducing the amount of Fe catalyst in ATRP}

Efforts to reduce the catalyst amount while maintaining an acceptable level of control for the chain growth process has received extensive attention in copper-mediated 
ATRP (see Introduction, Figure 5), driven by the desire for colourless polymer products without the need of extensive purification. However, iron-mediated ATRP has also been achieved in the presence of reducing agents that serve to maintain an operational amount of catalyst in the reduced (activator) state at very low concentration levels, including examples of ARGET, ICAR and SARA processes.

Fe-mediated ICAR ATRP has been shown to work in principle. ${ }^{93,137,141,201,212,225,229}$ $\mathrm{FeCl}_{3} \cdot 6 \mathrm{H}_{2} \mathrm{O}$ with triphenylphosphine ligands, AIBN as a thermal initiator to provide slowly generated radicals and 1,4-(2-bromo-2-methyl-propionato)benzene as an ATRP initiator affects the ICAR conditions and controls the radical polymerisation even at very low catalyst concentrations. ${ }^{93}$ Similar work reports the efficacy of these reactions in the absence of a thermal radical initiator. ${ }^{141} \mathrm{~A}$ highly efficient process can also be accomplished under SARA-ATRP conditions, using $\mathrm{Fe}(0)$ powder as the reducing agent. ${ }^{91,225}$

Additionally, the potential dual-role of ligating acids ${ }^{188-190,196,197,200}$ and salts ${ }^{225}$ in reversible deactivation radical polymerisation is evidenced by their prevalence in ARGET ATRP. Polymer scientists have used this strategy to prepare poly(acrylonitrile) decorated silica nanoparticles ${ }^{189}$ and polystyrene resins, ${ }^{188}$ as well as crosslinked networks ${ }^{190}$ and ionic-liquid based microemulsions. ${ }^{127}$ Similarly, ARGET ATRP conditions were used to modify silica nanoparticles ${ }^{90,102}$ and poly(vinylidene fluoride) ${ }^{92}$ by grafting PMMA chains onto their surfaces or chains. Little mechanistic study has been devoted to Fe-mediated ICAR, SARA and ARGET RDRP processes, with the assumption that the systems behave similarly to their copper counterparts. A thorough understanding of these systems is a ripe area for future research.

\subsection{AGET-ATRP: Is a reducing agent necessary?}

Analogous to $\mathrm{Cu}$-catalysed processes, the $\mathrm{Fe}$ complex acting as ATRP catalyst (generally a $\mathrm{Fe}^{\mathrm{II}}$ complex) has been generated in situ from more stable $\mathrm{Fe}^{\mathrm{III}}$ precursors in the presence of suitable reducing agents. ${ }^{81,85-87,91,92,94-98,100,102,104,136,139,140,142-}$ 148,175,185,202,206,219-221,223,226,227,231 Atom-transfer from alkyl halides can then establish the standard ATRP equilibrium. However, various contributions have reported well controlled polymerisations when using $\mathrm{Fe}^{\mathrm{III}}$ complexes and halide initiators in the absence of reducing agents or radical sources for the polymerisation of MMA and styrene. ${ }^{84,88,232}$ This is due to a spontaneous reduction of the $\mathrm{Fe}^{\mathrm{III}}$ complex by the monomer, to yield the activator $\mathrm{Fe}^{\mathrm{II}}$ complex in situ, rather than by an alternative ATRP activation equilibrium involving a $\mathrm{Fe}^{\mathrm{III}} / \mathrm{Fe}^{\mathrm{IV}}$ couple, and the method has been termed "Generation of Activators by Monomer Addition" (GAMA) ${ }^{88}$ This strategy also leads to the controlled polymerisation of MMA for $\mathrm{Cu}^{\mathrm{II}}$ salts in the presence of simple amine ligands. ${ }^{231,233}$ As the $\mathrm{Fe}^{\mathrm{III}}$ reduction is accompanied by monomer halogenations, ${ }^{84}$ the polymerisation can also take place by simply mixing the $\mathrm{Fe}^{\mathrm{III}}$ complex and monomer in the absence of initiator. ${ }^{101,234}$ However, 1,2dihaloisobutyrate (obtained by halogenations of MMA with $\mathrm{FeCl}_{3} / \mathrm{PPh}_{3}$ ) was proven unable to initiate the polymerisation of MMA. ${ }^{101}$ It therefore seems that the radical formed in the first step of the MMA halogenation process directly adds monomer to start the controlled chain growth (Figure 13). The presence of the $\mathrm{XCH}_{2}$ at the polymer $\alpha$ chain end was supported by ${ }^{1} \mathrm{H}$ and ${ }^{13} \mathrm{C}$ NMR spectroscopy. ${ }^{101}$ This method has so far been highlighted for Fe ${ }^{\mathrm{III}}$ only in the presence of phosphine ligands $\left(\mathrm{PPh}_{3}\right.$, 
$\mathrm{P}^{\mathrm{n}} \mathrm{Bu}_{3}, \mathrm{P}(\mathrm{OEt})_{3}$, DPPPy). The soft nature of the phosphorus donor atom stabilises the lower oxidation state system, rendering the $\mathrm{Fe}^{\mathrm{III}}$ complex more susceptible to spontaneous transfer of a halogen atom to the olefin.

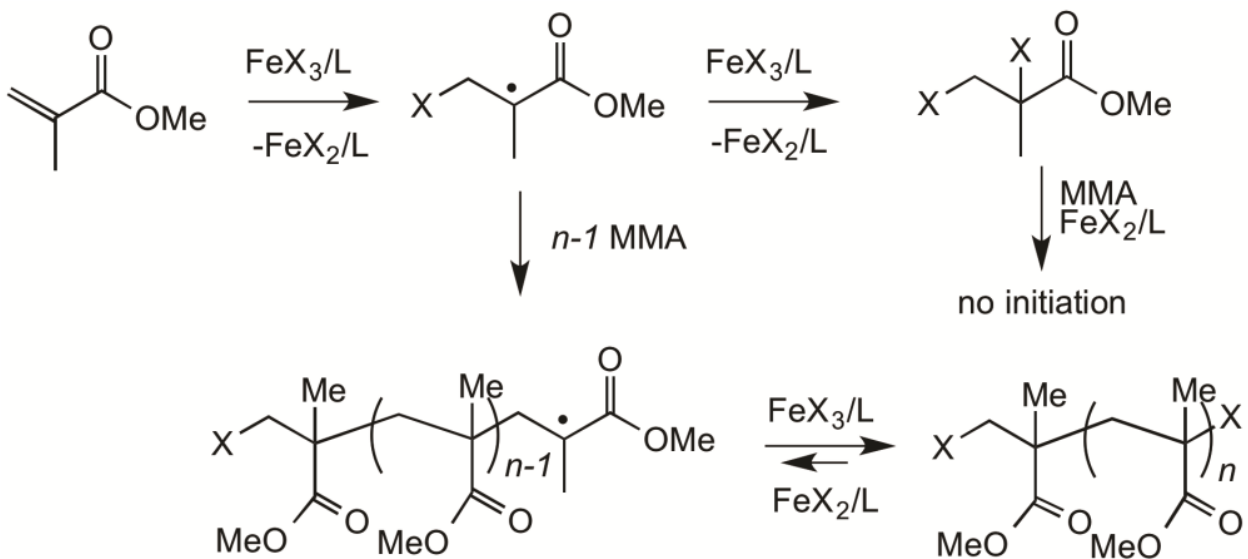

Figure 13. Mechanism of MMA polymerisation mediated by $\mathrm{FeX}_{3} / \mathrm{L}$ in the absence of reducing agents and initiators.

\subsection{Interplay of ATRP and RT-OMRP}

The ATRP and RT-OMRP controlling mechanisms do appear to interplay for styrene and MMA polymerisations in the presence of chloro-substituted amine-bis(phenolate) $\mathrm{Fe}^{\mathrm{III}}$ complexes, see Figure $9(\mathbf{B})$. This was initially suggested on the basis of the chain end analysis for the process set up under R-ATRP conditions, since only 30$35 \%$ of the recovered chains were found to be Cl-terminated. ${ }^{155,156}$ Subsequent studies have shown that the in situ reduction of the Fe ${ }^{\text {III }}$ complex with ascorbic acid or tin octanoate allows polymerisations to be initiated by both 1-phenylethyl chloride (ATRP regime) and AIBN (RT-OMRP regime), leading to good control in both cases (Figure 14). ${ }^{156}$ However, poor results were obtained when using excess radical initiator, indicating that a DT-OMRP pathway is not efficient for this system. The best control over the polymerisation is obtained using complexes where the groups decorating the phenolate ligands are electron-withdrawing, namely $\mathrm{Cl}$, whereas alkylsubstituted systems do not perform well. The reason for this peculiar effect, as rationalized by a more recent computational study by DFT, is related to the electron withdrawing effect of the $\mathrm{Cl}$ substituents. These substituents destabilize the oxidized $\mathrm{Fe}^{\mathrm{III}}-\mathrm{Cl}$ complex generated by $\mathrm{Cl}$ atom transfer from the dormant species, thereby increasing $K_{\text {ATRP }}$ with the effect of better moderating the free radical concentration. ${ }^{235}$ Complexes with $\mathrm{X}=\mathrm{Br}$ gave slower but better controlled polymerisations than those with $\mathrm{X}=\mathrm{Cl}$. 

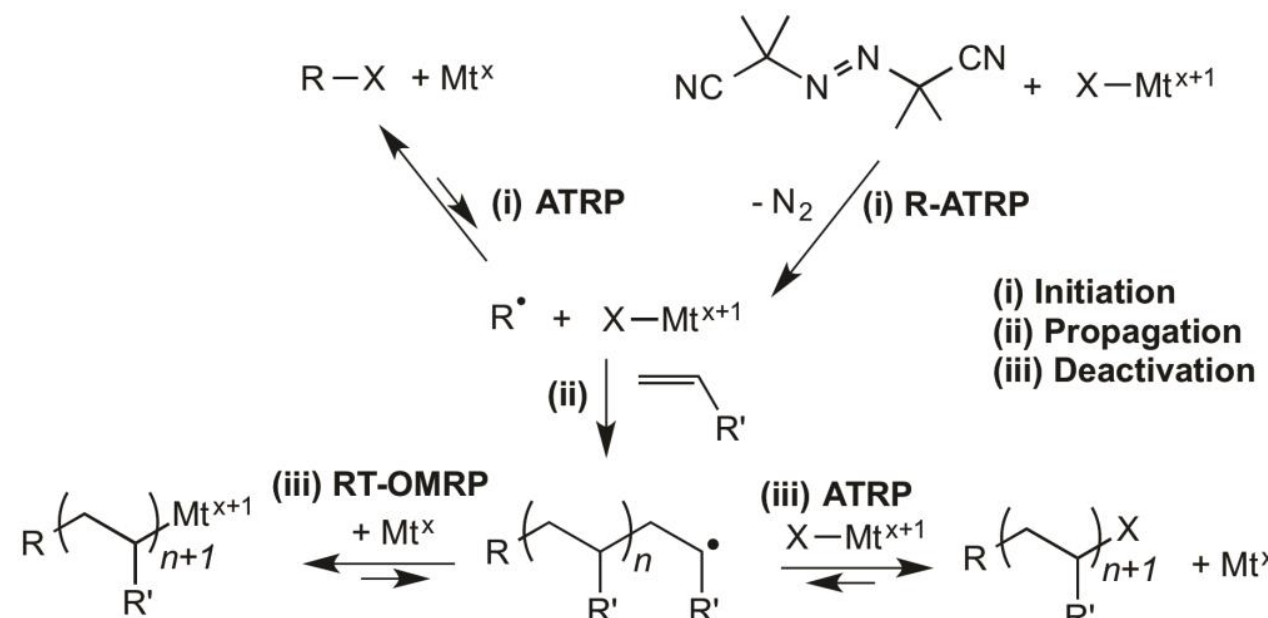

(iii) RT-OMRP

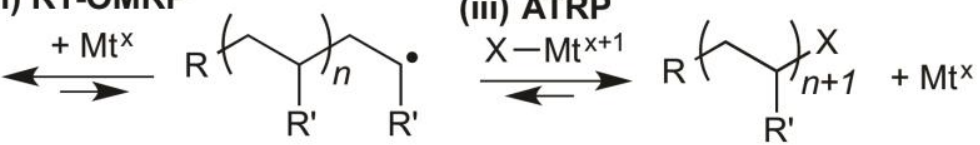

Figure 14. Interplay between ATRP and RT-OMRP controlling mechanisms.

Another system that deserves a brief comment within this section is $\left[\mathrm{CpFe}(\mathrm{CO})_{2}\right]_{2}$, introduced by Sawamoto as a mediator of acrylates, acrylamides and vinyl acetate. ${ }^{166,168}$ This system works best when used in combination with alkyl iodide initiators, meaning that the contribution of degenerate iodine-transfer processes cannot be excluded although the initial radical production undoubtedly results from an atom transfer process. However, the bimolecular initiation event, involving one molecule of $\left[\mathrm{CpFe}(\mathrm{CO})_{2}\right]_{2}$ and one molecule of R-I, would yield not only the organic radical $\mathrm{R}^{\cdot}$ and $\left[\mathrm{CpFe}(\mathrm{CO})_{2} \mathrm{I}\right]$ but also a metal-based radical, $\left[\mathrm{CpFe}(\mathrm{CO})_{2}\right]^{\circ}$, which is susceptible to trap the organic radical to form an organometallic species, $\left[\mathrm{CpFe}(\mathrm{CO})_{2}(\mathrm{R})\right]$. The possible intervention of an RT-OMRP equilibrium for this system has apparently not been considered and the use of this complex in an OMRP approach has not been reported, although $\left[\mathrm{CpFe}(\mathrm{CO})_{2}\right]_{2}$ has been tested as a chain transfer catalyst in radical polymerisation (vide infra).

\subsection{OMRP processes}

As discussed above, an OMRP process is always potentially present when the polymerisation occurs under ATRP conditions. However, pure OMRP processes (either dissociative, RT, or associative, DT) may occur in the absence of atom transfer when using complexes devoid of halogen atoms or other transferrable groups. Interest in this technique stems from the increased probability of controlling the polymerisation of monomers that are associated to more reactive radicals, such as vinyl acetate. Indeed, metal coordination sphere engineering allows tuning of both the Mt-C bond strength when working under RT-OMRP conditions, as demonstrated for vinyl acetate using $\mathrm{Co},{ }^{34,236,237} \mathrm{~V}^{238,239}$ and $\mathrm{Cr}^{240-242}$ complexes, and also the rate of associative exchange through the availability of open coordination sites when working under DT-OMRP conditions, as demonstrated for vinyl acetate using a cobalt porphyrin system. ${ }^{243}$ On the other hand, the C-X bond in the ATRP dormant species for this monomer is too strong leading to problematic reactivation.

In comparison to ATRP, the OMRP approach has the obvious disadvantage of requiring stoichiometric amounts of metal complex. The development of successful protocols using iron is therefore of great interest, given the low cost and toxicity of this metal. So far, reports of successful polymerisations by Fe-mediated OMRP are quite limited. After the early report by Claverie, discussed in section 2, of styrene 
polymerisation utilising $\mathrm{Fe}^{\mathrm{II}}$ porphyrin and Schiff base complexes, ${ }^{54}$ only one additional use of an Fe complex in a pure OMRP approach has been published to the best of our knowledge, which uses $\mathrm{Fe}(\mathrm{acac})_{2}$ for the RDRP of vinyl acetate. ${ }^{171}$ This system, however, suffers from aggregation problems leading to low initiator efficiencies and from slower radical trapping relative to its successful $\mathrm{Co}(\mathrm{acac})_{2}$ congener when used under RT-OMRP conditions ( $\leq 1$ equiv of radicals per Fe atom). The polymerisation is also controlled under DT conditions ( $>1$ equiv of radicals per Fe atom) but the full potential of this protocol remains to be established.

Additional investigations of Fe-mediated OMRP are warranted and have excellent potential for macromolecular synthesis. This requires better understanding of the coordination sphere effect on several key parameters: $(i)$ the homolytic strength of the $\mathrm{Fe}-\mathrm{C}$ bond; (ii) the relative barrier of the radical trapping process and the $\beta-\mathrm{H}$ atom transfer process (leading to CCT, Figure 3); (iii) the aptitude of the organometallic dormant species, $\mathrm{P}_{\mathrm{n}}-\mathrm{Fe}^{\mathrm{x}+1} / \mathrm{L}$, to react with another free radical (leading to catalysed termination, Figure 4). This latter phenomenon, only recently discovered for $\mathrm{Cu},{ }^{40}$ has so far not been reported for Fe but its potential occurrence cannot be excluded a priori. The potential competition between controlled growth and CCT is a very well established phenomenon for OMRP with other metals, especially Co. ${ }^{36,38}$ To our knowledge, the only report of CCT with an Fe complex (under pure OMRP conditions; see next section for a more complex situation) is in the patent literature and involves $\left[(\operatorname{ring}) \mathrm{Fe}(\mathrm{CO})_{2}\right]_{2}\left(\operatorname{ring}=\mathrm{Cp}, \mathrm{Cp}^{*}\right){ }^{244}$ The transfer constants of these catalysts, however, are low ( 0.5 for the $\mathrm{Cp}$ complex, 9 for the $\mathrm{Cp}^{*}$ complex, $c f .100$ for $\left[\mathrm{CpCr}(\mathrm{CO})_{3}\right]_{2}$ or $>40000$ for the most active cobaloximes $){ }^{38}$

In order to be an efficient spin trap for the growing radical chain, as well as an efficient chain transfer catalyst, a metal complex should have radical character, have an accessible one-electron oxidation and have a low activation barrier for the radical trapping (in RT-OMRP) or H-atom transfer process (in CCT). The most frequently used $\mathrm{Fe}^{\mathrm{II}}$ complexes typically have a high-spin ground state with four unpaired electrons $(\mathrm{S}=2)$, whereas the $\mathrm{Fe}^{\mathrm{III}}-\mathrm{R}$ OMRP dormant species and the putative $\mathrm{Fe}^{\mathrm{III}}-\mathrm{H}$ CCT intermediates are likely to adopt either a low-spin $(\mathrm{S}=1 / 2)$ or an intermediate spin $(\mathrm{S}=3 / 2)$ ground state because $\mathrm{H}$ and alkyls are strong field ligands. Indeed, most isolated alkyl iron(III) complexes have been shown to adopt a low-spin configuration, although there are exceptions. ${ }^{245}$ The OMRP dormant species for the above mentioned amine-bis(phenolate) Fe $\mathrm{F}^{\mathrm{III}}$ complex of Figure 9 (B) adopts an intermediate spin state ( $\mathrm{S}=3 / 2$ ) according to the DFT calculation. ${ }^{235}$ Hence, bond formation may involve not only pairing of one metal electron with the entering group unpaired electron but also pairing of two additional metal electrons. How this spin state change affects the relative rates of radical trapping and $\mathrm{H}$-atom transfer is an interesting question that has not so far been addressed.

\subsection{Interplay of ATRP, RT-OMRP and CCT}

One of the most intriguing $\mathrm{Fe}$ systems used in RDRP is $\left[\mathrm{FeCl}_{2}\left(\mathrm{R}^{1} \mathrm{~N}=\mathrm{C}\left(\mathrm{R}^{2}\right) \mathrm{C}\left(\mathrm{R}^{2}\right)=\mathrm{NR}^{1}\right]\right.$ (Figure 8), abbreviated as ${ }^{\mathrm{R} 1 \mathrm{R} 2}[\mathrm{NN}] \mathrm{FeCl}_{2}$, introduced by Gibson and co-workers and applied to the polymerisation of styrene and acrylate monomers. This system appears to act as either a mediator for controlled chain growth or as a chain transfer catalyst depending on the electronic properties of the diimine ligand. ${ }^{39,112,113,132-134}$ When $R_{2}$ is $H$, the system leads to controlled chain growth if $R_{1}$ 
= alkyl and to polymers with low-molecular weights that do not increase with conversion, indicating CCT, if $\mathrm{R}_{2}=$ aryl. ${ }^{132}$ However, the nature of $\mathrm{R}_{2}$ also plays a role because when $R_{1}=$ alkyl, the system demonstrates CCT activity when $R_{2}$ is an aryl group (with the exception of $p-\mathrm{Me}_{2} \mathrm{NC}_{6} \mathrm{H}_{4}$ ). A correlation was found with the spin state of the related ${ }^{\mathrm{R} 1 \mathrm{R} 2}[\mathrm{NN}] \mathrm{FeCl}_{3}$ complex: CCT occurs when the $\mathrm{Fe}^{\mathrm{III}}$ complex has an intermediate-spin state $(\mathrm{S}=3 / 2)$ whereas controlled chain growth is observed when the $\mathrm{Fe}^{\mathrm{III}}$ complex is high-spin $(\mathrm{S}=5 / 2) .{ }^{39,133}$ The polymerisations were carried out under ATRP conditions (organic halide initiator). Therefore, the systems leading to controlled chain growth appear to operate through an ATRP mechanism, with the possible intervention of some reversible RT-OMRP trapping. The systems resulting in CCT are proposed to favour RT-OMRP trapping, followed by a transfer process that occurs via $\beta-\mathrm{H}$ elimination from the OMRP dormant species, rather than by direct $\mathrm{H}^{*}$ transfer from the chain carrier radical to the $\mathrm{Fe}^{\mathrm{II}}$ complex, see Figure 15. Mechanistic studies investigated the low-temperature generation of the putative alkyliron(III) species in situ by alkylation of ${ }^{\mathrm{R} 1 \mathrm{R} 2}[\mathrm{NN}] \mathrm{FeCl}_{3}$. Alkyl derivatives obtained from highspin trichloride precursors, which favour controlled polymer growth by ATRP, are unstable above $-78^{\circ} \mathrm{C}$, whereas those obtained from intermediate-spin precursors, which favour CCT, are stable up to $-30^{\circ} \mathrm{C} .{ }^{134}$ Thus, the greater "carbophilicity" of the intermediate-spin complexes was proposed to favour radical trapping, leading to CCT via the OMRP dormant state, whereas the high-spin systems do not have sufficient affinity to form a bond with the chain carrier radicals and therefore do not promote CCT. The system was investigated computationally, ${ }^{246}$ however the reactions studied did not directly probe the ATRP vs. CCT reaction pathways. It is interesting to note the marked difference between this system and the aminebis(phenolate) system of Figure 9 (B). They lead to isoelectronic RT-OMRP dormant species (15-electron $\mathrm{FeX}_{3} \mathrm{~L}_{2}$ according to the Green classification) but whereas the dichloride diimine ligand system proceeds to rapid $\beta-\mathrm{H}$ elimination (CCT), the aminebis(phenolate) system yields controlled chain growth by RT-OMRP.<smiles>[R]C1=[N+]([R])[P+](Cl)(Cl)(Cl)(Cl)N([R])C1[R]</smiles><smiles>[R]O[R7]#N</smiles><smiles></smiles>

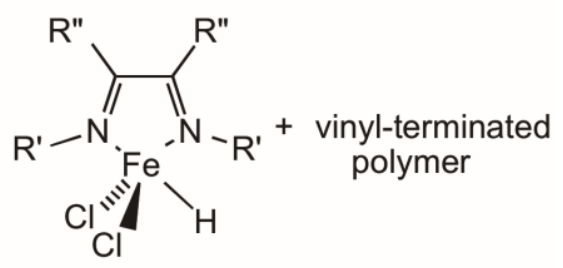

Figure 15. Interplay of ATRP, OMRP-RT and CCT in styrene polymerisation with $\alpha$ diimine iron complexes.

It is also worthwhile to recognise iron's robust history in polymerisation reactions. The interplay in these polymerisation reactions may not be limited to only radical reactions. Iron complexes have been used under coordination-insertion polymerisation 
conditions in instances where the mechanism is debated or uncertain. For instance, the $\mathrm{FeR}_{2}$ (bipy) ${ }_{2}$ and $\mathrm{FeR}_{2}$ (bipy) $2 / \mathrm{AlEt}_{3}$ systems have been used for the polymerisation of acrylonitrile. In these systems, the possibility of coordination-insertion, anionic and radical reactions exist. While efforts to elucidate the mechanism have been made, there remains uncertainty in the actual mode of action. The interface between radical and other polymerisation mechanisms in iron- and, in fact, all metal-mediated RDRP remains an interesting, if challenging, field of study. ${ }^{247-249}$

\subsection{Lessons Learned in Designing Fe Systems for RDRP}

Significant unknowns remain in the design of new, improved systems for ironmediated reversible deactivation radical polymerisation. Specifically, are there unified answers to optimal coordination geometry, stereoelectronic properties, spin state or redox properties for Fe-based RDRP? From the manuscripts gathered herein, few clear trends exist. Recent reports on the enhanced activity of ATRP Fe catalysts containing electron-donating aryl substituents on the phosphine ligands for both styrene and methacrylate monomers illustrate the importance of systematic variation of ligand electronics. ${ }^{99,106}$ In copper systems, clear linear relationships exist in many of these cases. Matyjaszewski and co-workers have developed relationships between ligands and the activation rate constant for copper systems, with multidentate, electron-rich amines being favoured, while also showing that a branched topology favours high reaction rates. ${ }^{25,250-252}$ Similarly, a linear relationship between the oneelectron redox potential of copper complexes is noted, tracking with $\mathrm{K}_{\mathrm{ATRP}}$ and $\mathrm{k}_{\text {act. }}{ }^{251,252}$ To draw these conclusions from the presented iron literature is challenging. No clear trend in redox potential and polymerisation rates is noted, although this is complicated by the lack of electrochemical measurements on many reported systems. The variability of spin state for both oxidation states (particularly $\mathrm{Fe}^{\mathrm{III}}$ ) may in part be responsible for this. The best performing systems do feature multi-dentate ligand frameworks, especially those with strong covalent bonds. Within this subset, however, active catalysts are promoted by inclusion of electron-withdrawing ${ }^{155,156}$ and electrondonating ${ }^{135,157}$ substituents. Many other active systems run competently in the absence of an added ligand source. We feel that the lack of clear trends and design guidance from the iron literature is often due to the non-systematic approach to Fe-mediated RDRP discovery, coupled with the more complicated coordination chemistry of ironbased systems. Using only coordinate-covalent bonds to support the more labile iron complexes can lead to multiple speciation and open up other reactivity pathways. Performance, as measured by the observed dispersity, correlates well with the rate of polymerization, suggesting that it is not inefficient chain exchange but rather competing reaction pathways such as CCT or catalyst decomposition that lead to a loss of control. Iron systems, especially when supported by mono- or bi-dentate ligands, will readily aggregate and disproportionate into multiple complexes. The true nature of the active species in these systems is often not known. As Fe-mediated RDRP is also further complicated by the complex interrelationship between halogenophilic and carbophilic reaction pathways, a deep understanding has yet to be achieved. Fe ${ }^{\mathrm{II}}$ appears to have greater propensity than $\mathrm{Cu}^{\mathrm{I}}$ to trap radicals and generate the RT-OMRP dormant species. Indeed, reports of radical trapping by $\mathrm{Cu}^{\mathrm{I}}$ are very limited, ${ }^{40,253}$ which reflects the weakness of $\mathrm{Cu}^{\mathrm{II}}$-alkyl bonds. Developing pure OMRP protocols with $\mathrm{Fe}$ appears as a tantalizing prospect, which requires the development of coordination spheres disfavouring the $\beta-\mathrm{H}$ elimination process for the $\mathrm{Fe}^{\mathrm{III}}$-alkyl dormant species. We believe that a renewed focus on a systematic approach to developing iron complexes and a revisitation of previously published ligand sets and 
complexes to gather electrochemical and speciation data may reveal much in the coming years.

Can any recommendations be made? What complex should be used for iron-mediated controlled-radical polymerisations? There is no perfect iron complex that is suitable to all conditions. The amine-bis(phenolate) iron complexes (Figure 9, B) are likely the best choice for the polymerisation of styrene and its derivatives; Matyjasewski's porphyrin iron derivatives (Figure 9, C) perform extremely well for acrylate derivatives and especially water-soluble monomers. Beyond these overly simplistic recommendations is the realisation that iron's role in these reactions remains poorly understood and much work remains to be done.

\section{Conclusions}

Iron is an inexpensive, active, environmentally-benign and increasingly researched alternative to copper-mediated Atom Transfer Radical Polymerisation. A growing focus on iron-mediated reversible deactivation radical polymerisations has led to significant advances in ligand and complex design, monomer scope, macrostructure control and mechanistic understanding. From this field's birth in 1997, ligand choice has grown to include simple phosphine ligands, multidentate imines and amines, cyclopentadienyls, acids, acetylacetonates, salts and designer multi-dentate frameworks that ensure well-defined coordination chemistry. While initial discoveries in iron-mediated RDRP could not compete with the exemplar performance of copper systems, extensive development has led to systems that offer dispersities as low as 1.1 and rapid polymerisation rates, which are competitive with the top copper systems. The scope for these reactions is growing as well, with over 30 monomers controlled, allowing the functionalisation of surfaces or particles and the production of block copolymers and polymer brushes. The systems can operate by classical ATRP strategies using alkyl halides as initiators, but more frequently exploit conventional radical initiators and the more stable $\mathrm{Fe}^{\mathrm{III}}$ metal complexes. Protocols for using iron complexes in ICAR, SARA, ARGET and AGET ATRPs have also been reported. Alongside excellent performance, iron systems raise intriguing mechanistic questions, with many systems operating at the interface between classical ATRP, OMRP, CCT and coordination-insertion polymerisation mechanisms. Together, these scientific advances provide an excellent foundation for the continued growth of iron-mediated RDRP in academia and industry. The next generation of advances in this field will hopefully be aided by this review, and will benefit from logical complex development, systematic investigation of reaction mechanism and pursuit of a widened monomer and macrostructure scope.

\section{Acknowledgment}

RP thanks the Centre National de la Recherche Scientifique, the Institut Universitaire de France, and the Agence National de la Recherche (grant «OMRP», ANR-10BLAN-0710) for funding. MS thanks the University of Edinburgh, the University of Prince Edward Island and the Marie Curie Actions Programme (Career Integration Grant) for funding.

\section{References}


(1) Cacioli, P.; Hawthorne, D. G.; Laslett, R. L.; Rizzardo, E.; Solomon, D. H. J. Macromol. Sci., Part A: Chem. 1986, 23, 839-852.

(2) Meijs, G. F.; Rizzardo, E. Makromol. Chem. Rapid Commun. 1988, 9, 547-551.

(3) Meijs, G. F.; Rizzardo, E.; Thang, S. H. Macromolecules 1988, 21, 3122-3124.

(4) Wayland, B. B.; Poszmik, G.; Fryd, M. Organometallics 1992, 11, 3534-3542.

(5) Georges, M. K.; Veregin, R. P. N.; Kazmaier, P. M.; Hamer, G. K. Macromolecules 1993, 26, 2987-2988.

(6) Wayland, B. B.; Poszmik, G.; Mukerjee, S. J. Am. Chem. Soc. 1994, $116,7943-7944$.

(7) Wang, J.-S.; Matyjaszewski, K. J. Am. Chem. Soc. 1995, 117, 56145615.

(8) Kato, M.; Kamigaito, M.; Sawamoto, M.; Higashimura, T. Macromolecules 1995, 28, 1721-1723.

(9) Puts, R. D.; Sogah, D. Y. Macromolecules 1996, 29, 3323-3325.

(10) Charmot, D.; Corpart, P.; Adam, H.; Zard, S. Z.; Biadatti, T.; Bouhadir, G. Macromol. Symp. 2000, 150, 23-32.

3688.

(11) Hawker, C. J.; Bosman, A. W.; Harth, E. Chem. Rev. 2001, 101, 3661-

(12) Matyjaszewski, K.; Xia, J. Chem. Rev. 2001, 101, 2921-2990.

(13) Moad, G.; Rizzardo, E.; Thang, S. H. Aust. J. Chem. 2005, 58, 379-

410.

(14) Moad, G.; Rizzardo, E.; Thang, S. H. Aust. J. Chem. 2006, 59, 669-

692.

(15) David, G.; Boyer, C.; Tonnar, J.; Ameduri, B.; Lacroix-Desmazes, P.; Boutevin, B. Chem. Rev. 2006, 106, 3936-3962. 1142.

(16) Moad, G.; Rizzardo, E.; Thang, S. H. Acc. Chem. Res. 2008, 41, 1133-

(17) Moad, G.; Rizzardo, E.; Thang, S. H. Polymer 2008, 49, 1079-1131.

(18) Sciannamea, V.; Jérôme, R.; Detrembleur, C. Chem. Rev. 2008, 108, 1104-1126.

(19) Matyjaszewski, K.; Tsarevsky, N. V. Nat. Chem. 2009, 1, 276-288.

(20) Gao, H.; Matyjaszewski, K. Prog. Polym. Sci. 2009, 34, 317-350.

(21) Debuigne, A.; Poli, R.; Jérôme, C.; Jérôme, R.; Detrembleur, C. Prog. Polym. Sci. 2009, 34, 211-239.

(22) Moad, G.; Rizzardo, E.; Thang, S. H. Aust. J. Chem. 2009, 62, 14021472.

(23) Yamago, S. Chem. Rev. 2009, 109, 5051-5068.

(24) Ouchi, M.; Terashima, T.; Sawamoto, M. Chem. Rev. 2009, 109, 49635050 .

(25) di Lena, F.; Matyjaszewski, K. Prog. Polym. Sci. 2010, 35, 959-1021.

(26) Hurtgen, M.; Detrembleur, C.; Jérôme, C.; Debuigne, A. Polym. Rev. 2011, 51, 188-213.

(27) Allan, L. E. N.; Perry, M. R.; Shaver, M. P. Prog. Polym. Sci. 2012, $37,127-156$.

(28) Moad, G.; Rizzardo, E.; Thang, S. H. Chem. Asian J. 2013, 8, 16341644. 
(29) Nicolas, J.; Guillaneuf, Y.; Lefay, C.; Bertin, D.; Gigmes, D.; Charleux, B. Prog. Polym. Sci. 2013, 38, 63-235.

(30) Fischer, H. Chem. Rev. 2001, 101, 3581-3610.

(31) Goto, A.; Fukuda, T. Prog. Polym. Sci. 2004, 29, 329-385.

(32) Poli, R. Angew. Chem., Int. Ed. 2006, 45, 5058-5070.

(33) Wayland, B. B.; Peng, C.-H.; Fu, X.; Lu, Z.; Fryd, M. Macromolecules 2006, 39, 8219-8222.

(34) Maria, S.; Kaneyoshi, H.; Matyjaszewski, K.; Poli, R. Chem. Eur. J. 2007, 13, 2480-2492.

(35) Le Grognec, E.; Claverie, J.; Poli, R. J. Am. Chem. Soc. 2001, 123, 9513-9524.

(36) Santhosh Kumar, K. S.; Gnanou, Y.; Champouret, Y.; Daran, J.-C.; Poli, R. Chem. Eur. J. 2009, 15, 4874-4885.

(37) Min, K.; Gao, H.; Matyjaszewski, K. J. Am. Chem. Soc 2005, 127, 3825-3830.

(38) Gridnev, A. A.; Ittel, S. D. Chem. Rev. 2001, 101, 3611-3659.

(39) Shaver, M. P.; Allan, L. E. N.; Rzepa, H. S.; Gibson, V. C. Angew. Chem. Int. Ed. 2006, 45, 1241-1244.

(40) Schröder, K.; Konkolewicz, D.; Poli, R.; Matyjaszewski, K. Organometallics 2012, 31, 7994-7999.

(41) Poli, R. Eur. J. Inorg. Chem. 2011, 1513-1530.

(42) Jakubowski, W.; Min, K.; Matyjaszewski, K. Macromolecules 2006, $39,39-45$.

(43) Matyjaszewski, K.; Jakubowski, W.; Min, K.; Tang, W.; Huang, J. Y.; Braunecker, W. A.; Tsarevsky, N. V. Proc. Natl. Acad. Sci. U. S. A. 2006, 103, 15309-15314.

(44) Braunecker, W. A.; Matyjaszewski, K. Prog. Polym. Sci. 2007, 32, $93-$ 146.

(45) Zhang, Y. Z.; Wang, Y.; Peng, C. H.; Zhong, M. J.; Zhu, W. P.; Konkolewicz, D.; Matyjaszewski, K. Macromolecules 2012, 45, 78-86.

(46) Magenau, A. J. D.; Strandwitz, N. C.; Gennaro, A.; Matyjaszewski, K. Science 2011, 332, 81-84.

(47) Rosen, B. M.; Percec, V. Chem. Rev. 2009, 109, 5069-5119.

(48) Konkolewicz, D.; Wang, Y.; Zhong, M. J.; Krys, P.; Isse, A. A.; Gennaro, A.; Matyjaszewski, K. Macromolecules 2013, 46, 8749-8772.

(49) Kamigaito, M.; Ando, T.; Sawamoto, M. Chem. Rev. 2001, 101, 36893745 .

(50) Ouchi, M.; Terashima, T.; Sawamoto, M. Acc. Chem. Res. 2008, 41, $1120-1132$.

(51) Ando, T.; Kamigaito, M.; Sawamoto, M. Macromolecules 1997, 30, 4507-4510.

(52) Poli, R.; Stoffelbach, F.; Maria, S.; Mata, J. Chem. Eur. J. 2005, 11, 2537-2548.

(53) Matyjaszewski, K.; Wei, M.; Xia, J.; McDermott, N. E. Macromolecules 1997, 30, 8161-8164.

(54) Claverie, J. P. Res. Discl. 1998, 416, P1595-P1604.

(55) Moineau, G.; Dubois, P.; Jérôme, R.; Senninger, T.; Teyssié, P. Macromolecules 1998, 31, 545-547.

(56) Paik, H.-j.; Teodorescu, M.; Xia, J.; Matyjaszewski, K. Macromolecules 1999, 32, 7023-7031. 
(58) Kotani, Y.; Kamigaito, M.; Sawamoto, M. Macromolecules 1999, 32, $6877-6880$.

(59) Chen, X.-P.; Qiu, K.-Y. Macromolecules 1999, 32, 8711-8715.

(60) Chen, X.-P.; Qiu, K.-Y. Chem. Commun. 2000, 233-234.

(61) Chen, X.-P.; Qiu, K.-Y. Chem. Commun. 2000, 1403-1404.

(62) Chen, X.-P.; Qiu, K.-Y. Polym. Int. 2000, 49, 1529-1533.

(63) Chen, X.-P.; Qiu, K.-Y. New J. Chem. 2000, 24, 865-869.

(64) Chen, X.-P.; Qiu, K.-Y. J. Appl. Polym. Sci. 2000, 77, 1607-1613.

(65) Qin, D.-Q.; Qin, S.-H.; Chen, X.-P.; Qiu, K.-Y. Polymer 2000, 41, 7347-7353.

(66) Qin, D.-Q.; Qin, S.-H.; Qiu, K.-Y. J. Polym. Sci., Part A: Polym. Chem. 2000, 38, 101-107.

(67) Yamamoto, K.; Miwa, Y.; Tanaka, H.; Sakaguchi, M.; Shimada, S. J. Polym. Sci., Part A: Polym. Chem. 2002, 40, 3350-3359.

(68) Ibrahim, K.; Löfgren, B.; Seppälä, J. Eur. Polym. J. 2003, 39, 939-944.

(69) Qiu, K.-Y.; Li, P.; Chen, X.-P. Macromol. Symp. 2003, 195, 33-38.

(70) Yamamoto, K.; Tanaka, H.; Sakaguchi, M.; Shimada, S. Polymer 2003, 44, 7661-7669.

(71) Ibrahim, K.; Starck, P.; Lofgren, B.; Seppala, J. J. Polym. Sci., Part A: Polym. Chem. 2005, 43, 5049-5061.

(72) Jian, C.; Chen, J.; Zhang, K. J. Polym. Sci., Part A: Polym. Chem. 2005, 43, 2625-2631.

(73) Zhang, H.; Xu, D.-M.; Zhang, K.-D. Chin. J. Chem. 2005, 23, 913917.

(74) Hou, C.; Qu, R.; Ji, C.; Wang, C.; Wang, C. Polym. Int. 2006, 55, 326329.

(75) Aydogan, B.; Yagci, Y. Turk. J. Chem. 2007, 31, 1-10.

(76) Hou, C.; Ying, L. J. Appl. Polym. Sci. 2007, 104, 4041-4045.

(77) Uchiike, C.; Terashima, T.; Ouchi, M.; Ando, T.; Kamigaito, M.; Sawamoto, M. Macromolecules 2007, 40, 8658-8662.

(78) Feng, Y.; Feng, J.; Zhao, J.; Wang, Y. Polymer 2007, 48, 1581-1585.

(79) Gong, R.; Maclaughlin, S.; Zhu, S. Appl. Surf. Sci. 2008, 254, 68026809.

(80) Uchiike, C.; Ouchi, M.; Ando, T.; Kamigaito, M.; Sawamoto, M. J. Polym. Sci., Part A: Polym. Chem. 2008, 46, 6819-6827.

(81) Zhang, L.; Cheng, Z.; Tang, F.; Li, Q.; Zhu, X. Macromol. Chem. Phys. 2008, 209, 1705-1713.

(82) Xue, Z.; Linh, N. T. B.; Noh, S. K.; Lyoo, W. S. Angew.Chem. Int. Ed. 2008, 47, 6426-6429.

(83) Xue, Z.; Oh, H. S.; Noh, S. K.; Lyoo, W. S. Macromol. Rapid Commun. 2008, 29, 1887-1894.

(84) Xue, Z.; He, D.; Noh, S. K.; Lyoo, W. S. Macromolecules 2009, 42, 2949-2957.

(85) Tang, F.; Zhang, L.; Zhu, J.; Cheng, Z.; Zhu, X. Ind. Eng. Chem. Res. 2009, 48, 6216-6223.

(86) Zhang, L.; Cheng, Z.; Zhang, Z.; Xu, D.; Zhu, X. Polym. Bull. 2010, 64, 233-244. 
(87) Li, Q.; Zhang, L.; Zhang, Z.; Zhou, N.; Cheng, Z.; Zhu, X. J. Polym. Sci., Part A: Polym. Chem. 2010, 48, 2006-2015.

(88) He, D.; Xue, Z.; Khan, M. Y.; Noh, S. K.; Lyoo, W. S. J. Polym. Sci., Part A: Polym. Chem. 2010, 48, 144-151.

(89) Pizarro, G. d. C.; Marambio, O. G.; Jeria-Orell, M.; Flores, M. E.; Rivas, B. L. J. Appl. Polym. Sci. 2010, 118, 3649-3657.

(90) Du, S.; Zhou, G.; Wang, X.; Li, T.; Xu, Y.; Zhang, L. Micro Nano Lett. 2011, 6, 154-156.

(91) Qin, J.; Cheng, Z.; Zhang, L.; Zhang, Z.; Zhu, J.; Zhu, X. Macromol. Chem. Phys. 2011, 212, 999-1006.

(92) Zhao, T.; Zhang, L.; Zhang, Z.; Zhou, N.; Cheng, Z.; Zhu, X. J. Polym. Sci., Part A: Polym. Chem. 2011, 49, 2315-2324.

(93) Zhu, G.; Zhang, L.; Zhang, Z.; Zhu, J.; Tu, Y.; Cheng, Z.; Zhu, X. Macromolecules 2011, 44, 3233-3239.

(94) He, W.; Zhang, L.; Bai, L.; Zhang, Z.; Zhu, J.; Cheng, Z.; Zhu, X. Macromol. Chem. Phys. 2011, 212, 1474-1480.

(95) Xu, W.; Cheng, Z.; Zhang, Z.; Zhang, L.; Zhu, X. React. Funct. Polym. 2011, 71, 634-640.

(96) Bergenudd, H.; Jonsson, M.; Malmstroem, E. J. Mol. Catal. A: Chem. 2011, 346, 20-28.

(97) Jiang, H.; Zhang, L.; Pan, J.; Jiang, X.; Cheng, Z.; Zhu, X. J. Polym. Sci., Part A: Polym. Chem. 2012, 50, 2244-2253.

(98) Miao, J.; He, W.; Zhang, L.; Wang, Y.; Cheng, Z.; Zhu, X. J. Polym. Sci., Part A: Polym. Chem. 2012, 50, 2194-2200.

(99) Wang, Y.; Kwak, Y.; Matyjaszewski, K. Macromolecules 2012, 45, 5911-5915.

(100) Miao, J.; Jiang, H.; Zhang, L.; Wu, Z.; Cheng, Z.; Zhu, X. RSC Adv. 2012, 2, 840-847.

(101) Khan, M. Y.; Chen, X.; Lee, S. W.; Noh, S. K. Macromol. Rapid Commun. 2013, 34, 1225-1230.

(102) Zhang, L.; Zhou, G.; Sun, B.; Chen, F.; Zhao, M.; Li, T. Macromol. Chem. Phys. 2013, 214, 1602-1611.

(103) Pan, J.; Miao, J.; Zhang, L.; Si, Z.; Zhang, C.; Cheng, Z.; Zhu, X. Polym. Chem. 2013, 4, 5664-5670.

(104) Wang, Y.; Bai, L.; Chen, W.; Chen, L.; Liu, Y.; Xu, T.; Cheng, Z. Polym. Bull. 2013, 70, 631-642.

(105) Aoshima, H.; Satoh, K.; Umemura, T.; Kamigaito, M. Polym. Chem. 2013, 4, 3554-3562.

(106) Nishizawa, K.; Ouchi, M.; Sawamoto, M. Macromolecules 2013, 46, 3342-3349.

(107) Satoh, K.; Aoshima, H.; Kamigaito, M. J. Polym. Sci., Part A: Polym. Chem. 2008, 46, 6358-6363.

(108) Khan, M. Y.; Chen, X.; Noh, S. K. Macromol. Res. 2013, 21, 442-449.

(109) Xue, Z.; Lee, B. W.; Noh, S. K.; Lyoo, W. S. Polymer 2007, 48, 47044714.

(110) Xue, Z.; Noh, S. K.; Lyoo, W. S. Macromol. Res. 2007, 15, 302-307.

(111) Xue, Z.; Noh, S. K.; Lyoo, W. S. J. Polym. Sci., Part A: Polym. Chem. 2008, 46, 2922-2935.

(112) Gibson, V. C.; O'Reilly, R. K.; Reed, W.; Wass, D. F.; White, A. J. P.; Williams, D. J. Chem. Commun. 2002, 1850-1851. 
(113) Gibson, V. C.; O'Reilly, R. K.; Wass, D. F.; White, A. J. P.; Williams, D. J. Macromolecules 2003, 36, 2591-2593.

(114) Göbelt, B.; Matyjaszewski, K. Macromol. Chem. Phys. 2000, 201, $1619-1624$.

(115) Gibson, V. C.; O'Reilly, R. K.; Wass, D. F.; White, A. J. P.; Williams, D. J. Dalton Trans. 2003, 2824-2830.

(116) O'Reilly, R. K.; Gibson, V. C.; White, A. J. P.; Williams, D. J. Polyhedron 2004, 23, 2921-2928.

(117) Zhang, H.; Schubert, U. S. J. Polym. Sci., Part A: Polym. Chem. 2004, 42, 4882-4894.

(118) Zhang, H.; Schubert, U. S. Chem. Commun. 2004, 858-859.

(119) Abu-Surrah, A.; Ibrahim, K. A.; Abdalla, M. Y.; Issa, A. A. J. Polym. Res. 2011, 18, 59-66.

(120) Matyjaszewski, K.; Coca, S.; Gaynor, S. G.; Wei, M.; Woodworth, B. E. Macromolecules 1997, 30, 7348-7350.

(121) Saikia, P. J.; Goswami, A.; Baruah, S. D. J. Appl. Polym. Sci. 2002, 86, 386-394.

(122) Saikia, P. J.; Goswami, A.; Baruah, S. D. J. Appl. Polym. Sci. 2002, 85, 1236-1245.

(123) Zhang, H.; Marin, V.; Fijten, M. W. M.; Schubert, U. S. J. Polym. Sci., Part A: Polym. Chem. 2004, 42, 1876-1885.

(124) Viau, L.; Even, M.; Maury, O.; Haddleton, D. M.; Le, B. H. C. $R$. Chim. 2005, 8, 1298-1307.

(125) Saikia, P. J.; Dass, N. N.; Baruah, S. D. J. Appl. Polym. Sci. 2005, 97, 2147-2154.

(126) Ferro, R.; Milione, S.; Caruso, T.; Grassi, A. J. Mol. Catal. A: Chem. 2009, 307, 128-133.

(127) Wang, G.-X.; Lu, M.; Liu, L.-C.; Wu, H.; Zhong, M. J. Appl. Polym. Sci. 2013, 128, 3077-3083.

(128) Saikia, P. J.; Baruah, S. D. Polym. Bull. 2013, 70, 3291-3303.

(129) Saikia, P. J.; Hazarika, A. K.; Baruah, S. D. Polym. Bull. 2013, 70, $1483-1498$.

(130) Ferro, R.; Milione, S.; Bertolasi, V.; Capacchione, C.; Grassi, A. Macromolecules 2007, 40, 8544-8546.

(131) Ferro, R.; Milione, S.; Erra, L.; Grassi, A. Inorg. Chem. Commun. 2008, $11,535-538$.

(132) O'Reilly, R. K.; Shaver, M. P.; Gibson, V. C.; White, A. J. P. Macromolecules 2007, 40, 7441-7452.

(133) Allan, L. E. N.; Shaver, M. P.; White, A. J. P.; Gibson, V. C. Inorg. Chem. 2007, 46, 8963-8970.

(134) Shaver, M. P.; Allan, L. E. N.; Gibson, V. C. Organometallics 2007, $26,4725-4730$.

(135) O'Reilly, R. K.; Gibson, V. C.; White, A. J. P.; Williams, D. J. J. Am. Chem. Soc. 2003, 125, 8450-8451.

(136) Luo, R.; Sen, A. Macromolecules 2008, 41, 4514-4518.

(137) Wang, G.; Lu, M.; Wu, H. Polymer 2012, 53, 1093-1097.

(138) Wang, G.; Zhu, X.; Zhu, J.; Cheng, Z. J. Polym. Sci., Part A: Polym. Chem. 2006, 44, 483-489.

(139) Bai, L.; Zhang, L.; Zhu, J.; Cheng, Z.; Zhu, X. J. Polym. Sci., Part A: Polym. Chem. 2009, 47, 2002-2008. 
(140) Zhang, L.; Cheng, Z.; Lü, Y.; Zhu, X. Macromol. Rapid Commun. 2009, 30, 543-547.

(141) Zhang, L.; Miao, J.; Cheng, Z.; Zhu, X. Macromol. Rapid Commun. 2010, 31, 275-80.

(142) Liu, J.; He, W.; Zhang, L.; Zhang, Z.; Zhu, J.; Yuan, L.; Chen, H.; Cheng, Z.; Zhu, X. Langmuir 2011, 27, 12684-92.

(143) Guo, T.; Zhang, L.; Jiang, H.; Zhang, Z.; Zhu, J.; Cheng, Z.; Zhu, X. Polym. Chem. 2011, 2, 2385-2390.

(144) He, W.; Zhang, L.; Zhu, G.; Zhang, Z.; Zhou, N.; Cheng, Z.; Zhu, X. J. Controlled Release 2011, 152, e210-e211.

(145) Tao, M.; Zhang, L.; Jiang, H.; Zhang, Z.; Zhu, J.; Cheng, Z.; Zhu, X. Macromol. Chem. Phys. 2011, 212, 1481-1488.

(146) He, W.; Zhang, L.; Miao, J.; Cheng, Z.; Zhu, X. Macromol. Rapid Commun. 2012, 33, 1067-73.

(147) He, W.; Cheng, L.; Zhang, L.; Liu, Z.; Cheng, Z.; Zhu, X. ACS Appl. Mater. Interfaces 2013, 5, 9663-9669.

(148) He, W.; Cheng, L.; Zhang, L.; Liu, Z.; Cheng, Z.; Zhu, X. Polym. Chem. 2014, 5, 638-645.

(149) Ibrahim, K.; Yliheikkilä, K.; Abu-Surrah, A.; Löfgren, B.; Lappalainen, K.; Leskelä, M.; Repo, T.; Seppälä, J. Eur. Polym. J. 2004, 40, $1095-$ 1104.

(150) Chen, J.; Chu, J.; Zhang, K. Polymer 2004, 45, 151-155.

(151) Chen, J.; Zhang, H.; Chu, J.; Zhang, K. J. Macromol. Sci., Pure Appl. Chem. 2005, A42, 95-103.

(152) Hao, J.; Li, H.; Zhu, X. X. Biomacromolecules 2006, 7, 995-998.

(153) Niibayashi, S.; Hayakawa, H.; Jin, R.-H.; Nagashima, H. Chem. Commun. 2007, 1855-1857.

(154) Kawamura, M.; Sunada, Y.; Kai, H.; Koike, N.; Hamada, A.; Hayakawa, H.; Jin, R.-H.; Nagashima, H. Adv. Synth. Catal. 2009, 351, 2086-2090.

(155) Allan, L. E. N.; MacDonald, J. P.; Reckling, A. M.; Kozak, C. M.; Shaver, M. P. Macromol. Rapid Commun. 2012, 33, 414-418.

(156) Allan, L. E. N.; MacDonald, J. P.; Nichol, G. S.; Shaver, M. P. Macromolecules 2014, 47, 1249-1257.

(157) Simakova, A.; Mackenzie, M.; Averick, S. E.; Park, S.; Matyjaszewski, K. Angew. Chem. Int. Ed. 2013, 52, 12148-12151.

(158) Cao, J.; Chen, J.; Zhang, K.; Shen, Q.; Zhang, Y. Appl. Catal., A 2006, $311,76-78$.

(159) Qin, D.-Q.; Qin, S.-H.; Qiu, K.-Y. J. Polym. Sci., Part A: Polym. Chem. 2001, 39, 3464-3473.

(160) Qin, S.-H.; Qin, D.-Q.; Qiu, K.-Y. New J. Chem. 2001, 25, 893-895.

(161) Qin, S.-H.; Qin, D.-Q.; Qiu, K.-Y. Chin. J. Polym. Sci. 2001, 19, 441445.

(162) Cao, J.; Zhang, L.; Jiang, X.; Tian, C.; Zhao, X.; Ke, Q.; Pan, X.; Cheng, Z.; Zhu, X. Macromol. Rapid Commun. 2013, 34, 1747-1754.

(163) Kotani, Y.; Kamigaito, M.; Sawamoto, M. Macromolecules 2000, 33, 3543-3549.

(164) Kotani, Y.; Kamigaito, M.; Sawamoto, M. Macromolecules 2000, 33, 6746-6751.

(165) Fuji, Y.; Ando, T.; Kamigaito, M.; Sawamoto, M. Macromolecules 2002, 35, 2949-2954. 
(166) Kamigaito, M.; Onishi, I.; Kimura, S.; Kotani, Y.; Sawamoto, M. Chem. Commun. 2002, 2694-2695.

(167) Onishi, I.; Baek, K.-Y.; Kotani, Y.; Kamigaito, M.; Sawamoto, M. J. Polym. Sci., Part A: Polym. Chem. 2002, 40, 2033-2043.

(168) Wakioka, M.; Baek, K.-Y.; Ando, T.; Kamigaito, M.; Sawamoto, M. Macromolecules 2002, 35, 330-333.

(169) Islamova, R. M.; Monakov, Y. B. Polym. Sci., Ser. C 2011, 53, 27-34.

(170) Louie, J.; Grubbs, R. H. Chem. Commun. 2000, 1479-1480.

(171) Xue, Z.; Poli, R. J. Polym. Sci., Part A: Polym. Chem. 2013, 51, 34943504.

(172) Wang, Y.; Matyjaszewski, K. Macromolecules 2010, 43, 4003-4005.

(173) Bulgakova, S. A.; Tumakova, E. S.; Zhizhikina, A. V.; Zaitsev, S. D.; Kurushina, L. V.; Semchikov, Y. D. Polym. Sci., Ser. B 2011, 53, 57-63.

(174) Bulgakova, S. A.; Volgutova, E. S.; Kiseleva, E. A.; Khokhlova, I. E.; Semchikov, Y. D. Polym. Sci., Ser. B 2011, 53, 563-567.

(175) Bulgakova, S. A.; Volgutova, E. S.; Khokhlova, I. E. Open J. Polym. Chem. 2012, 2, 99-104.

(176) Schroeder, H.; Yalalov, D.; Buback, M.; Matyjaszewski, K. Macromol. Chem. Phys. 2012, 213, 2019-2026.

(177) Schroeder, H.; Buback, M.; Matyjaszewski, K. Macromol. Chem. Phys. 2014, 215, 44-53.

(178) Ng, Y.-H.; Lena, F.; Chai, C. L. Macromol. Res. 2012, 20, 552-558.

(179) Deng, K.; Zhang, Y.; Liu, Y.; Shi, Z.; Wang, Y. Chem. J. Internet 2002, 4, 59.

(180) Bergenudd, H.; Jonsson, M.; Nystroem, D.; Malmstroem, E. J. Mol. Catal. A: Chem. 2009, 306, 69-76.

(181) Wu, Y.; Wan, G.; Xu, J.; Cheng, S.; Fang, P. Adv. Polym. Technol. 2013, 32, 21364/1-21364/7.

2165.

(182) Wang, G.; Zhu, X.; Cheng, Z.; Zhu, J. Eur. Polym. J. 2003, 39, 2161-

(183) Zhu, S.; Yan, D. J. Polym. Sci., Part A: Polym. Chem. 2000, 38, 43084314.

(184) Zhu, S.; Yan, D. Macromol. Rapid Commun. 2000, 21, 1209-1213.

(185) Zhang, L.; Cheng, Z.; Shi, S.; Li, Q.; Zhu, X. Polymer 2008, 49, 3054-

3059.

(186) Hou, C.; Liu, J.; Wang, C. Polym. Int. 2006, 55, 171-175.

(187) Hou, C.; Qu, R.; Liu, J.; Guo, Z.; Wang, C.; Ji, C.; Sun, C.; Wang, C. Polymer 2006, 47, 1505-1510.

(188) Zong, G.; Chen, H.; Qu, R.; Wang, C.; Ji, N. J. Hazard Mater. 2011, $186,614-21$.

(189) Zong, G.; Chen, H.; Tan, Z.; Wang, C.; Qu, R. Polym. Adv. Technol. 2011, 22, 2626-2632.

(190) Zong, G.; Ma, J.; Chen, H.; Wang, C.; Ji, N.; Liu, D. J. Appl. Polym. Sci. 2012, 124, 2179-2186.

(191) Zhu, S.; Yan, D. Macromolecules 2000, 33, 8233-8238.

(192) Zhu, S.; Xiao, G.; Yan, D. J. Polym. Sci., Part A: Polym. Chem. 2001, 39, 2943-2950.

(193) Chen, H.; Qu, R.; Ji, C.; Wang, C.; Wang, C. J. Polym. Sci., Part A: Polym. Chem. 2006, 44, 219-225. 
(194) Hou, C.; Guo, Z.; Liu, J.; Ying, L.; Geng, D. J. Appl. Polym. Sci. 2007, 104, 1382-1385.

(195) Hou, C.; Ji, C.; Qu, R.; Wang, C.; Sun, C.; Zhou, W.; Yu, M. J. Appl. Polym. Sci. 2007, 105, 1575-1580.

(196) Chen, H.; Wang, C.; Liu, D.; Wang, M.; Ji, C. J. Appl. Polym. Sci. 2011, 122, 3298-3302.

(197) Chen, H.; Yang, L.; Liang, Y.; Hao, Z.; Lu, Z. J. Polym. Sci., Part A: Polym. Chem. 2009, 47, 3202-3207.

(198) Liang, Y.; Chen, H.; Zhou, W. J. Macromol. Sci., Part A: Pure Appl. Chem. 2009, 46, 759-764.

(199) Zhu, S.; Yan, D.; Zhang, G.; Li, M. Macromol. Chem. Phys. 2000, 201, 2666-2669.

(200) Wang, G.; Lu, M. e-Polym. 2012, 1, 629-636.

(201) Wang, G.; Lu, M.; Liu, Y. J. Appl. Polym. Sci. 2012, 126, 381-386.

(202) Wang, G. Iran. Polym. J. 2011, 20, 931-938.

(203) Hou, C.; Qu, R.; Ying, L.; Wang, C. J. Appl. Polym. Sci. 2006, 99, 32-

36.

(204) Hou, C.; Ying, L.; Wang, C. J. Appl. Polym. Sci. 2006, 99, 1050-1054.

(205) Hou, C.; Qu, R.; Ji, C.; Wang, C.; Sun, C. J. Appl. Polym. Sci. 2006, 101, 1598-1601.

(206) Deng, Z.; Guo, J.; Qiu, L.; Yuan, C.; Zhou, Y.; Yan, F. J. Polym. Sci., Part A: Polym. Chem. 2013, 51, 664-671.

(207) Zhou, W.; Chen, H.; Liang, Y.; Yu, M.; Chen, L. J. Appl. Polym. Sci. 2009, 114, 1593-1597.

(208) Zong, G.-X.; Chen, H.; Wang, C.-H.; Liu, D.-L.; Hao, Z.-H. J. Macromol. Sci., Part A: Pure Appl. Chem. 2010, 47, 804-808.

(209) Zhu, S.; Yan, D.; Zhang, G. Polym. Bull. 2001, 45, 457-464.

(210) Ma, J.; Chen, H.; Zong, G.; Wang, C.; Liu, D. J. Macromol. Sci., Part A: Pure Appl. Chem. 2010, 47, 1075-1079.

(211) Wang, G.; Zhu, X.; Cheng, Z.; Zhu, J. J. Polym. Sci., Part A: Polym. Chem. 2006, 44, 2912-2921.

(212) Wang, G.-X.; Lu, M.; Hou, Z.-H.; Gao, Y.; Liu, L.-C.; Wu, H. J. Appl. Polym. Sci. 2014, 131, DOI: 10.1002/APP.40135.

(213) Wang, G.; Wu, H. Polym. Bull. 2011, 67, 1809-1821.

(214) Al-Roomi, Y. M.; Hussain, K. F. J. Appl. Polym. Sci. 2014, 131, ASAP DOI: $10.1002 / A P P .39827$.

(215) Teodorescu, M.; Gaynor, S. G.; Matyjaszewski, K. Macromolecules 2000, 33, 2335-2339.

(216) Ishio, M.; Katsube, M.; Ouchi, M.; Sawamoto, M.; Inoue, Y. Macromolecules 2009, 42, 188-193.

(217) Sarbu, T.; Matyjaszewski, K. Macromol. Chem. Phys. 2001, 202, 3379-3391.

(218) Chen, H.; Meng, Y.; Liang, Y.; Lu, Z.; Lv, P. J. Mater. Res. 2009, 24, 1880-1885.

(219) Chen, H.; Liang, Y.; Liu, D.-L.; Tan, Z.; Zhang, S.-H.; Zheng, M.-L.; Qu, R.-J. Mater. Sci. Eng., C 2010, 30, 605-609.

(220) Deng, Z.; Guo, J.; Qiu, L.; Zhou, Y.; Xia, L.; Yan, F. Polym. Chem. 2012, 3, 2436-2443.

(221) Deng, Z.; Qiu, L.; Bai, L.; Zhou, Y.; Lin, B.; Zhao, J.; Cheng, Z.; Zhu, X.; Yan, F. J. Polym. Sci., Part A: Polym. Chem. 2012, 50, 1605-1610. 
(222) Wang, G.; Zhu, X.; Cheng, Z.; Zhu, J. J. Macromol. Sci., Pure Appl. Chem. 2004, A41, 487-499.

(223) Bai, L.; Zhang, L.; Zhang, Z.; Tu, Y.; Zhou, N.; Cheng, Z.; Zhu, X. Macromolecules 2010, 43, 9283-9290.

(224) Wang, Y.; Matyjaszewski, K. Macromolecules 2011, 44, 1226-1228.

(225) Wang, Y.; Zhang, Y.; Parker, B.; Matyjaszewski, K. Macromolecules 2011, 44, 4022-4025.

(226) Bai, L.; Zhang, L.; Zhang, Z.; Zhu, J.; Zhou, N.; Cheng, Z.; Zhu, X. J. Polym. Sci., Part A: Polym. Chem. 2011, 49, 3970-3979.

(227) Bai, L.; Zhang, L.; Zhang, Z.; Zhu, J.; Zhou, N.; Cheng, Z.; Zhu, X. J. Polym. Sci., Part A: Polym. Chem. 2011, 49, 3980-3987.

(228) Mukumoto, K.; Li, Y.; Nese, A.; Sheiko, S. S.; Matyjaszewski, K. Macromolecules 2012, 45, 9243-9249.

(229) Mukumoto, K.; Wang, Y.; Matyjaszewski, K. ACS Macro Lett. 2012, $1,599-602$.

(230) Yu, H.; Zhang, Z.; Cheng, Z.; Zhu, J.; Zhou, N.; Zhang, W.; Zhu, X. J. Polym. Sci., Part A: Polym. Chem. 2012, 50, 2182-2187.

$51,69-74$.

(231) Khan, M. Y.; Xue, Z.; He, D.; Noh, S. K.; Lyoo, W. S. Polymer 2010,

(232) Chen, X.; Khan, M. Y.; Noh, S. K. Polym. Chem. 2012, 3, 1971-1974.

(233) Becer, C. R.; Hoogenboom, R.; Fournier, D.; Schubert, U. S. Macromol. Rapid Commun. 2007, 28, 1161-1166.

(234) Bedri, B.; Cikilmazkaya, M.; Tunca, U.; Hizal, G. Designed Monomers and Polymers 2003, 6, 299-307.

(235) Poli, R.; Shaver, M. P. Inorg. Chem. in press.

(236) Debuigne, A.; Champouret, Y.; Jérôme, R.; Poli, R.; Detrembleur, C.

Chem. Eur. J. 2008, 14, 4046-4059.

(237) Debuigne, A.; Poli, R.; Jérôme, R.; Jérôme, C.; Detrembleur, C. ACS Symp. Ser. 2009, 1024, 131-148.

(238) Shaver, M. P.; Hanhan, M. E.; Jones, M. R. Chem. Commun. 2010, 46, 2127-2129.

(239) Allan, L. E. N.; Cross, E. D.; Francis-Pranger, T. W.; Hanhan, M. E.; Jones, M. R.; Pearson, J. K.; Perry, M. R.; Storr, T.; Shaver, M. P. Macromolecules 2011, 44, 4072-4081.

(240) Champouret, Y.; Baisch, U.; Poli, R.; Tang, L.; Conway, J. L.; Smith, K. M. Angew. Chem., Int. Ed. 2008, 47, 6069-6072.

(241) Champouret, Y.; MacLeod, K. C.; Baisch, U.; Patrick, B. O.; Smith, K.

M.; Poli, R. Organometallics 2010, 29, 167-176.

(242) Champouret, Y.; MacLeod, K. C.; Smith, K. M.; Poli, R. Organometallics 2010, 29, 3125-3132.

(243) Peng, C. H.; Scricco, J.; Li, S.; Fryd, M.; Wayland, B. B. Macromolecules 2008, 41, 2368-2373.

(244) Janowicz, A. H. U.S. Patent 47467131988.

(245) Poli, R. Chem. Rev. 1996, 96, 2135-2204.

(246) Johansson, M. P.; Swart, M. Dalton Trans. 2011, 40, 8419-8428.

(247) Yamamoto, A.; Yamamoto, T. J. Polym. Sci., Macromol. Rev. 1978, $13,161-218$.

(248) Schaper, F.; Foley, S. R.; Jordan, R. F. J. Am. Chem. Soc. 2004, 126, 2114-2124. 
(249) Yang, P.; Chan, B. C. K.; Baird, M. C. Organometallics 2004, 23, 2752-2761.

(250) Pintauer, T.; Matyjaszewski, K. Coord. Chem. Rev. 2005, 249, $1155-$ 1184.

(251) Tang, W.; Matyjaszewski, K. Macromolecules 2006, 39, 4953-4959.

(252) Tang, W.; Kwak, Y.; Braunecker, W.; Tsarevsky, N. V.; Coote, M. L.; Matyjaszewski, K. J. Am. Chem. Soc. 2008, 130, 10702-10713.

(253) Matyjaszewski, K.; Woodworth, B. E. Macromolecules 1998, 31, 4718-4723. 